Historic, archived document

Do not assume content reflects current scientific knowledge, policies, or practices. 

United States

Agriculture

Forest

Service

North Central

Forest Experiment

Station

Resource

Bulletin NC-153

Uins.

\section{Forest Statistics for}

Michigan's Western Upper Peninsula Unit, 1993

Earl C. Leatherberry
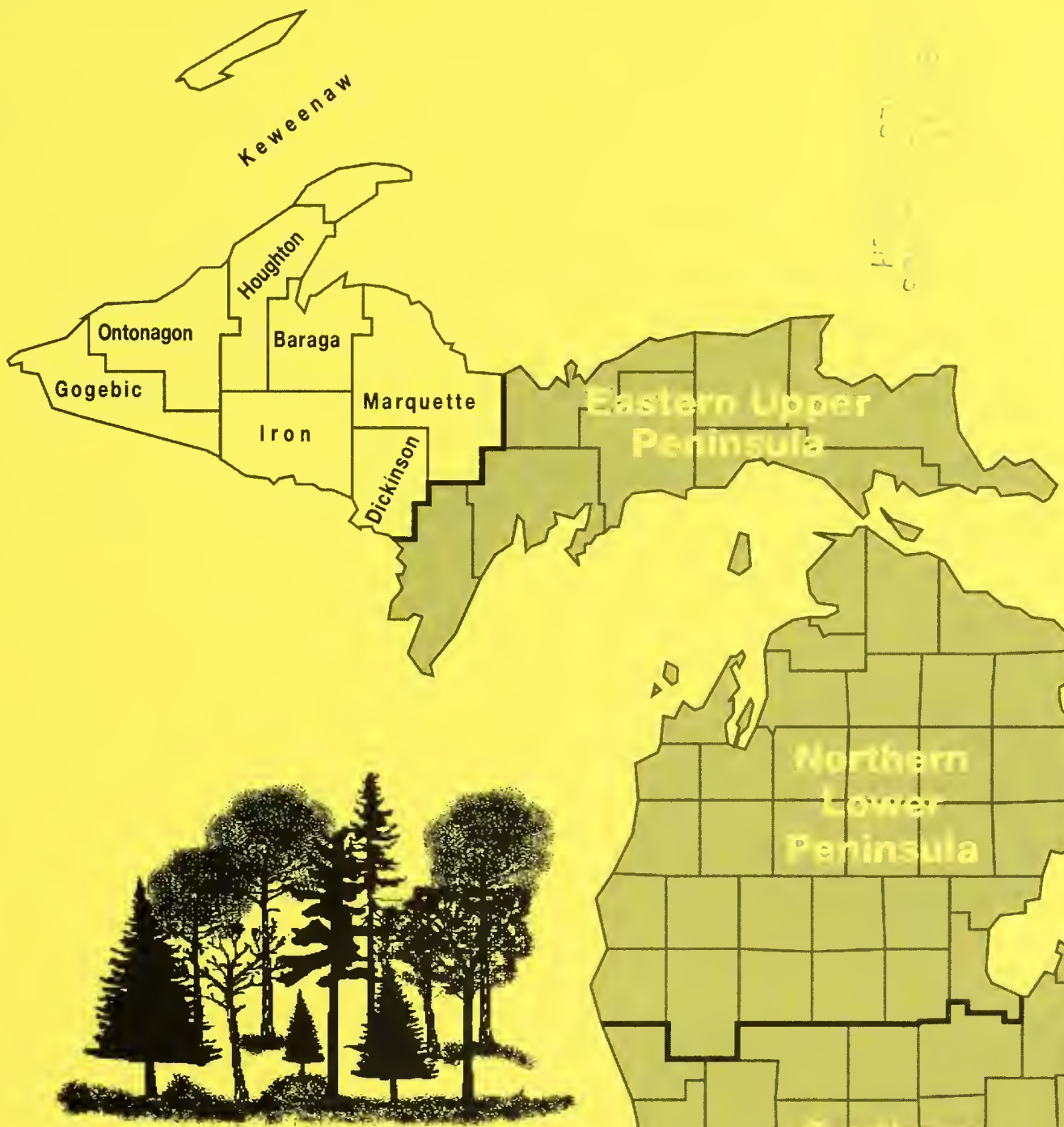

0
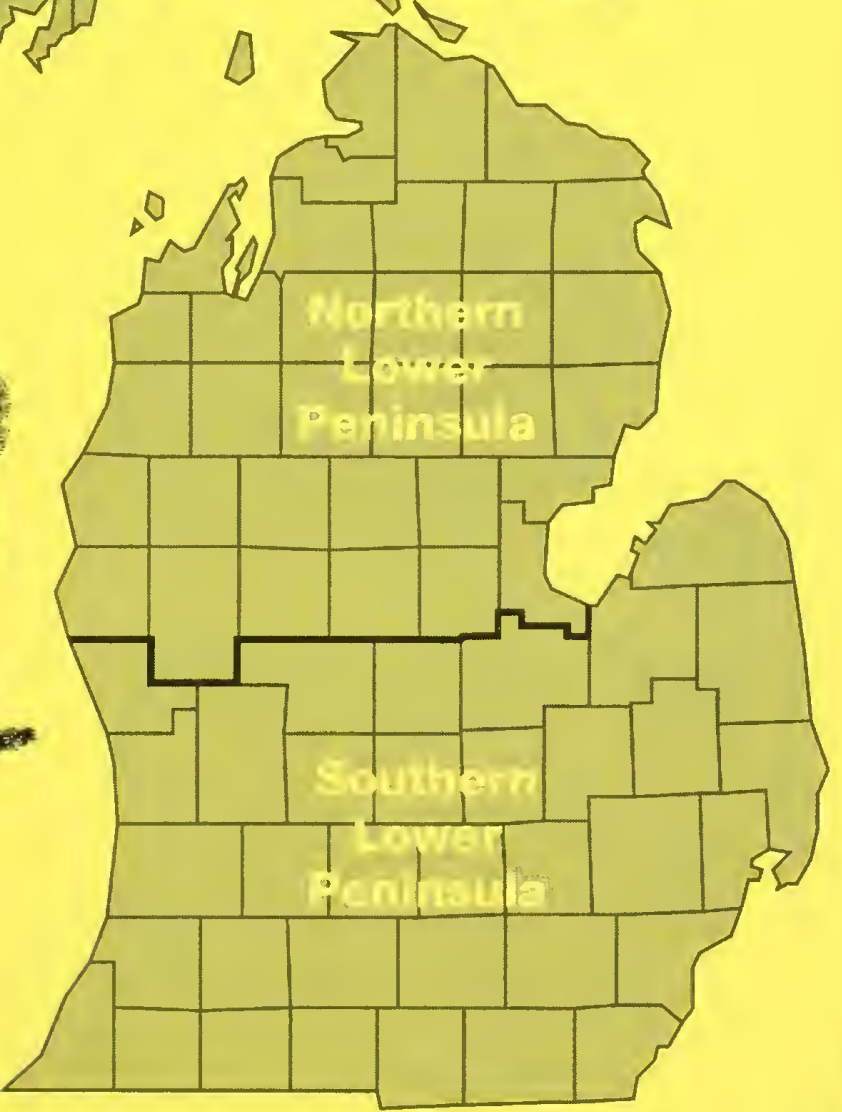
The United States Department of Agriculture (USDA) prohibits discrimination in its programs on the basis of race, color, natlonal origin, sex, rellgion, age, disability, political beliefs and marital or familial status. (Not all prohibited bases apply to all programs.) Persons with disabilities who require altemative means for communication of program Information (braille, large print, audiotape, etc.) should contact the USDA Office of Communication at (202) 720-5881 (voice) or (202) 720-7602 ? TDD).

To file a complaint, write the Secretary of Agriculture, U.S. Department of Agriculture, Washington, D.C. 20250 , or call (202) 720-7327 (voice) or (202) 720-1127 (TDD). USDA is an equal employment opportunity employer. 
This report includes the most commonly used Forest Inventory and Analysis (FIA) statistics from the U.S. Department of Agriculture, Forest Service.

Additional forest resource data can be provided to interested users. Persons requesting additional information from the raw inventory data are expected to pay the retrieval costs. These costs range from less than $\$ 100$ for a relatively simple request to more than $\$ 2,000$ for a complex retrieval involving the services of a Forest Inventory and Analysis computer programmer. Requests will be filled so as to minimize the impact on the Forest Inventory and Analysis Work Unit.

Requests for information may be directed to:

\author{
Project Leader \\ Forest Inventory and Analysis \\ North Central Forest Experiment Station \\ 1992 Folwell Avenue \\ St. Paul, Minnesota 55108 \\ Phone: (612) 649-5139 \\ or \\ State Forester \\ Michigan Department of Natural Resources \\ Forestry Division \\ P.O. Box 30028 \\ Lansing, Michigan 48909 \\ Phone: (517) 373-1275
}

Area served: Illinois, Indiana, Iowa, Kansas, Michigan, Minnesota, Missouri, Nebraska, North Dakota, South Dakota, Wisconsin. 
FLA is a continuing endeavor as mandated by the Renewable Resources Research Act of 1978. Prior inventories were mandated by the McSweeney-McNary Forest Research Act of 1928. The objective of FIA is to periodically inventory the Nation's forest land to determine its extent, condition, and volume of timber, growth, and removals. Up-to-date resource information is essential to frame forest policies and programs. USDA Forest Service regional experiment stations are responsible for conducting these inventories and publishing summary reports for individual States. The North Central Forest Experiment Station is responsible for forest inventory and analysis in Illinois, Indiana, Iowa, Kansas, Michigan, Minnesota, Missouri, Nebraska, North Dakota, South Dakota, and Wisconsin.

Fieldwork for the fifth forest inventory of Michigan's Western Upper Peninsula Unit was begun in April 1991 and completed in September 1992. Reports of the four previous inventories of Michigan's timber resource are dated 1935, 1955, 1966, and 1980.

More accurate survey information was obtained during this survey than otherwise would have been feasible because of intensified field sampling. Sampling intensity was tripled, providing reliable data at a county level. Such sampling was made possible through the cooperation, assistance, and additional funding provided by the Michigan Department of Natural Resources (MiDNR) and the Michigan State Legislature. To aid in determining current timber removals, MiDNR also surveyed primary woodusing plants in the State. Aerial photographs used were black and white, infrared taken in 1986 at a scale of 1:15,840 (nominal). These photographs were purchased by the MiDNR and loaned to the USDA Forest Service. 


\section{Contents}

Page

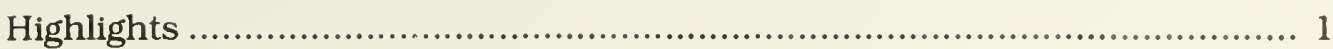

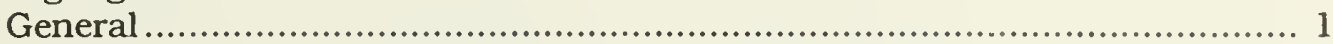

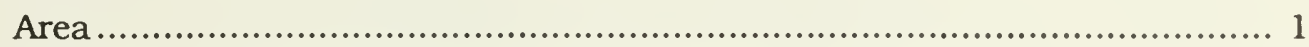

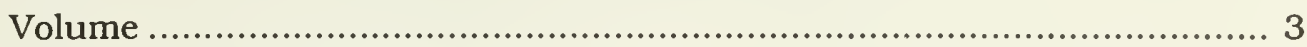

Timber Growth, Removals, and Mortality ........................................... 5

Growth .................................................................................... 5

Removals ......................................................................... 5

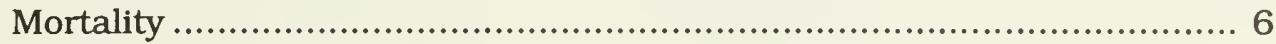

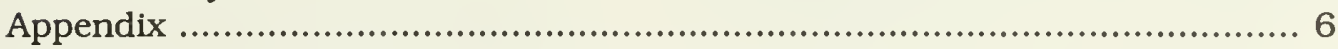

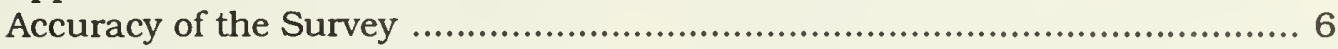

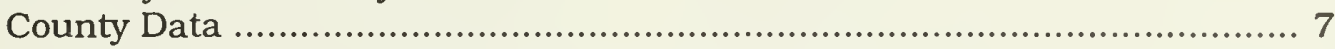

Comparing the Fifth Inventory of the Western Upper

Peninsula with the Fourth Inventory ........................................... 7

Survey Procedures ................................................................. 7

Major Steps in the New Survey Design .......................................... 8

Tree and $\log$ Grades ................................................................ 10

Metric Equivalents of Units Used in this Report ................................ 14

Tree Species Groups in Michigan's Western

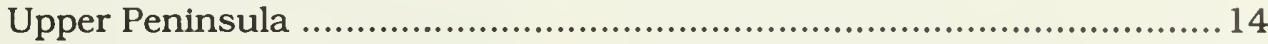

Definition of Terms .................................................................... 15

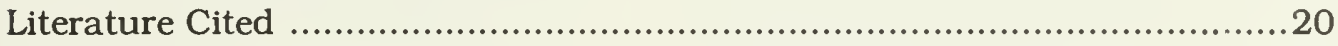

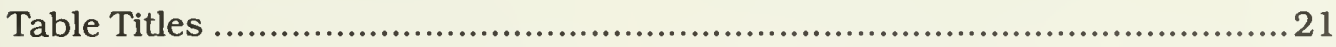

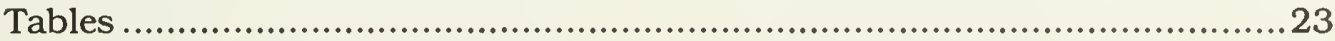





\title{
Forest Statistics for Michigan's Western Upper Peninsula Unit, 1993
}

\author{
Earl C. Leatherberry
}

\section{HIGHLIGHTS}

NOTE: Data from new forest inventories are often compared with data from earlier inventories to determine trends in forest resources. However, for the comparisons to be valid, the procedures used in the two inventories must be similar. As a result of our ongoing efforts to improve the inventory's efficiency and reliability, we have made several changes in procedures and definitions since the last Michigan inventory in 1980. Because some of these changes made it inappropriate to directly compare the 1993 data with those published for 1980, data from the 1980 inventory have been re-processed using the current procedures. Please refer to the appendix section labeled "Comparing the Fifth Inventory of the Western Upper Peninsula with the Fourth Inventory" for more details. The data in this report are subject to change when inventory data for the entire State have been compiled. It is expected, however, that any such changes will be minor.

\section{General}

The Western Upper Peninsula of Michigan (fig. 1) is comprised of eight counties. Natural resource exploitation has long driven the economy of the region. During the 1840's, one of the richest mining eras in American history was centered on the Keweenaw Peninsula, giving the region its current nickname of Copper Country. During the 1880's and 1890 's, most of the virgin stands of timber were cut and used to build the cities and towns of the Midwest. Later, iron ore mining dominated economic activity in the region. Today, nearly all the mines are closed, only

Earl C. Leatherberry is a Resource Analyst with the Forest Inventory and Analysis Unit, North Central Forest Experiment Station, St. Paul, Minnesota. remnant stands of the old growth timber remain, and younger trees now abound. Forest resources once again support much of the economic activity of the region.

In the Western Upper Peninsula, the deciduous and coniferous forests merge, in a region of unsurpassed beauty and charm. Several forested areas attract visitors seeking recreation experiences where solitude is valued; for example, the Sylvania, Sturgeon River Gorge, and McCormick National Wilderness Areas, administered by the Ottawa National Forest; and the Porcupine Mountain Wilderness State Park, and Isle Royale National Park. The region has some of the oldest exposed volcanic rock on Earth. The Huron, Keweenaw, and Porcupine Mountains possess landscapes that are uncommon in the Upper Midwest. During the winter, the hills and forests of the region are used for a variety of outdoor recreational activities. The diverse forest once again supports wildlife species, such as the eastern timber wolf and moose, which were nearly extinct in the area. The following are some major highlights from the 1993 inventory of Michigan's Western Upper Peninsula, with comparisons to 1980 , the year of the previous inventory.

\section{Area}

- In 1993 forest land accounted for 4.8 million acres ( 88 percent of the Unit's land area). The vast majority of forest land (95 percent) was classified timberland. Most of the remaining forest land was classified as reserved timberland.

- Between 1980 and 1993, total area of forest land in the Unit increased by 24,700 acres. This modest increase reverses a twodecade-long pattern of decline in forest land. 


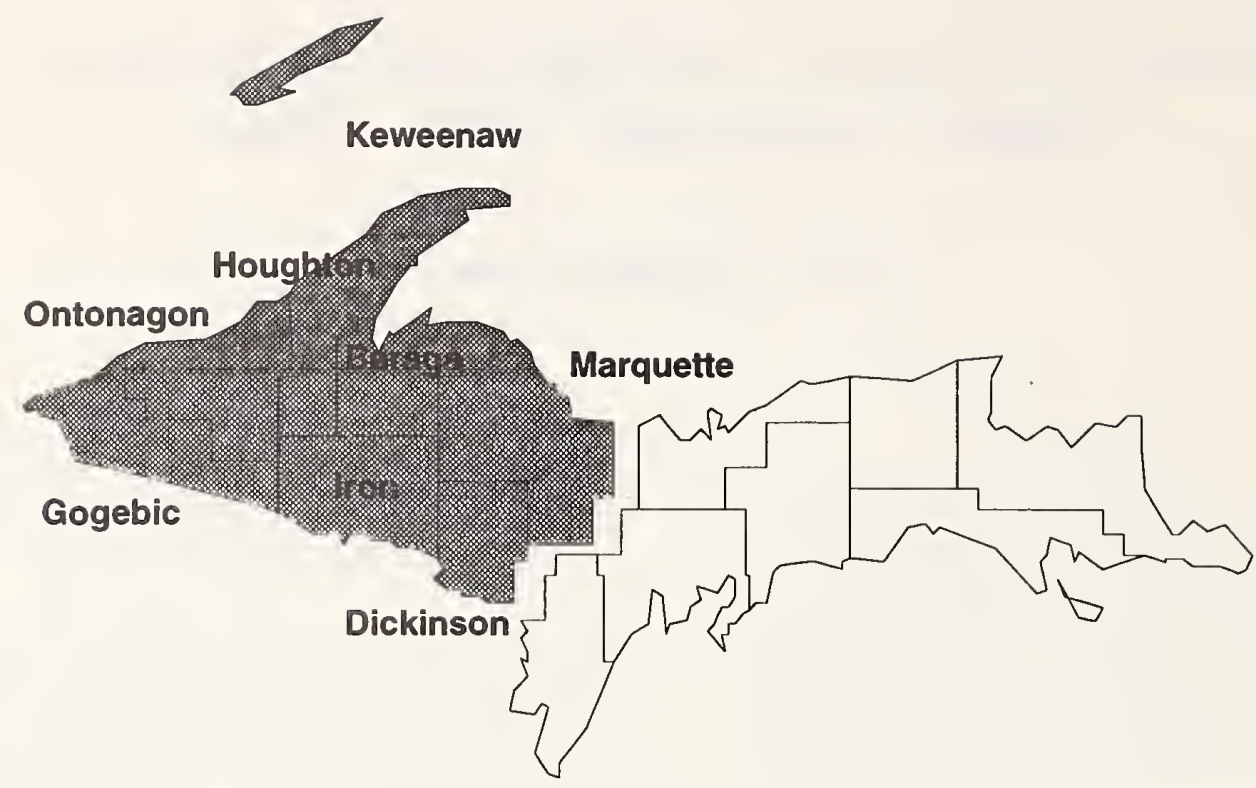

Figure 1.-Western Upper Peninsula Unit, 1993.

- Between inventories, timberland area increased by 83,800 acres. The increase in timberland resulted largely because land classed as unproductive forest land in 1980 was found to be marginally productive in 1993. Also, some land classed as productive-reserved in 1980 has been reclassified as timberland. Unproductive forest land and reserved timberland declined by 24,900 and 34,200 acres, respectively, between inventories.

- Marquette County contains 1 million acres of timberland-more timberland than in any other county in the Unit. Timberland area in Marquette County amounts to 22 percent of the Unit's total (fig. 2).

- Every county in the Unit is at least 80percent forested. In Gogebic and Keweenaw Counties, 9 of every 10 acres of land are forested.

- Forest industries (24 percent) and private individuals ( 24 percent) together own nearly half of the timberland in the Unit. Thirtyfour percent of the Unit's timberland area is publicly owned, the largest proportion (19 percent) being in the Ottawa National Forest. The remaining 18 percent is owned by miscellaneous corporations not engaged in the forest industry (fig. 3). Less than 1percent (6 thousand acres) of timberland is Indian owned.

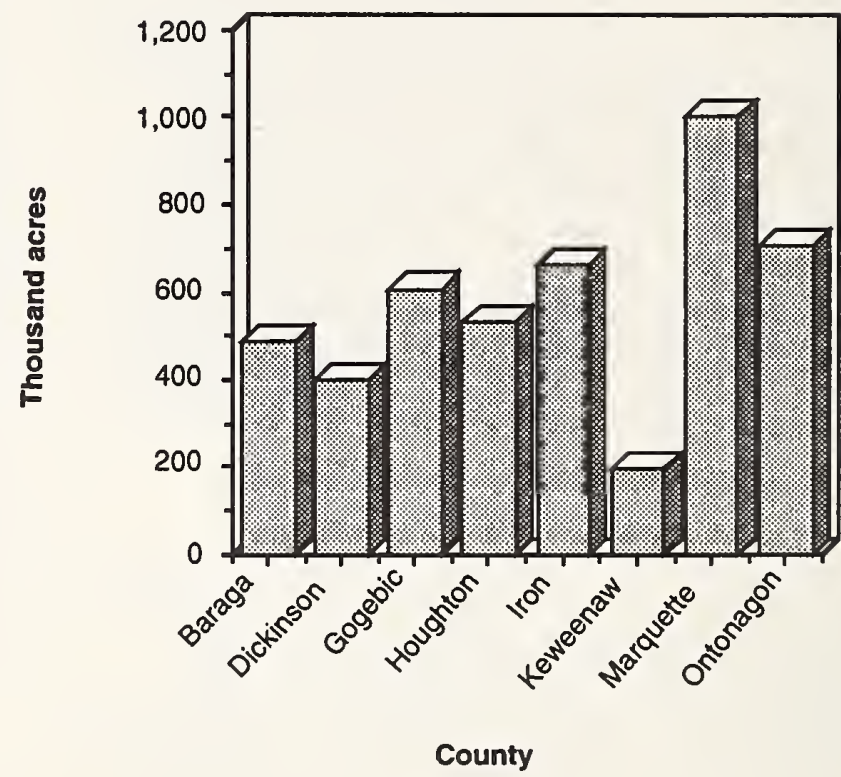

Figure 2.-Area of timberland by county, Western Upper Peninsula, 1993.

- The maple-birch forest type continues to dominate timberland area, occupying 54 percent of the timberland area, compared to 52 percent in 1980 (fig. 4).

- In 1993 almost half (49 percent) the Unit's timberland was in the sawtimber stand-size class. The area in sawtimber-size stands increased between inventories. In 1980 close to half ( 44 percent) of the timberland 


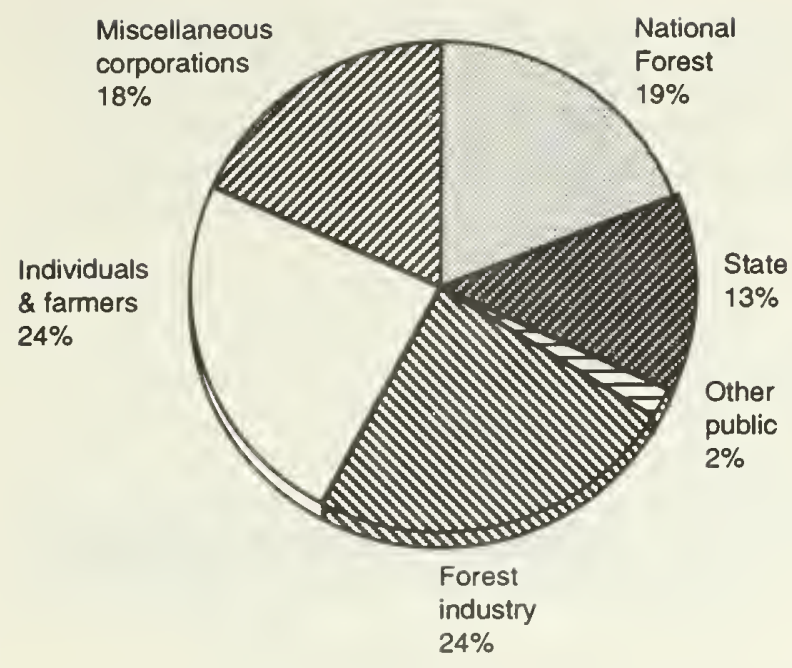

Figure 3.-Area of timberland by ownership class, Western Upper Peninsula, 1993.

was in poletimber stands compared to 28 percent in 1993. The increase in sawtimber-size stands and the corresponding decline in poletimber-size stands show the continuing maturation of forest stands in the Western Upper Peninsula. The area in sapling-seediling stands increased by 40 percent $(290,000$ acres) between inventories (fig. 5).

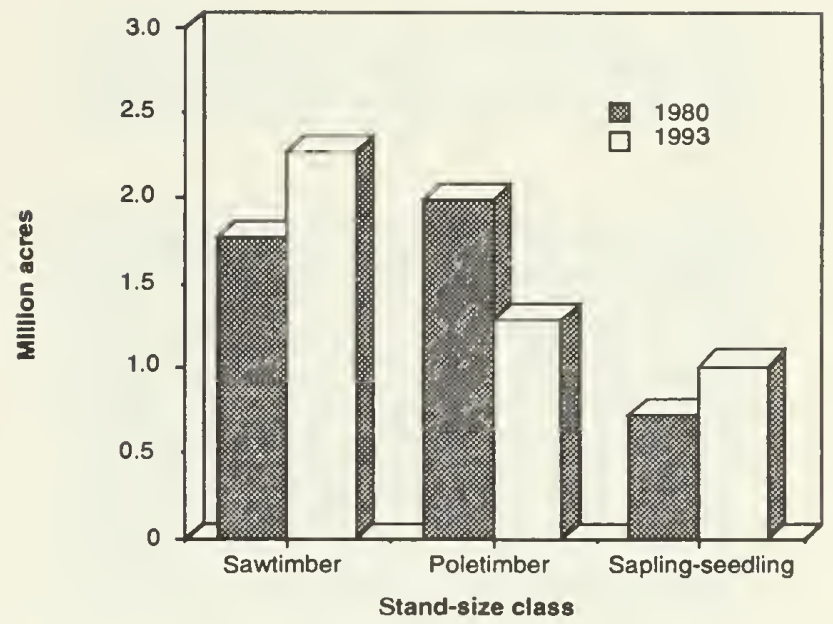

Figure 5.-Area of timberland by stand size class, Western Upper Peninsula, 1980 and 1993.

\section{Volume}

- Growing-stock volume on timberland increased 19 percent between inventories, from 6.2 billion cubic feet in 1980 to 7.3 billion cubic feet in 1993. Average growingstock volume per acre in 1993 was 1,590 cubic feet, compared to 1,365 cubic feet in 1980.

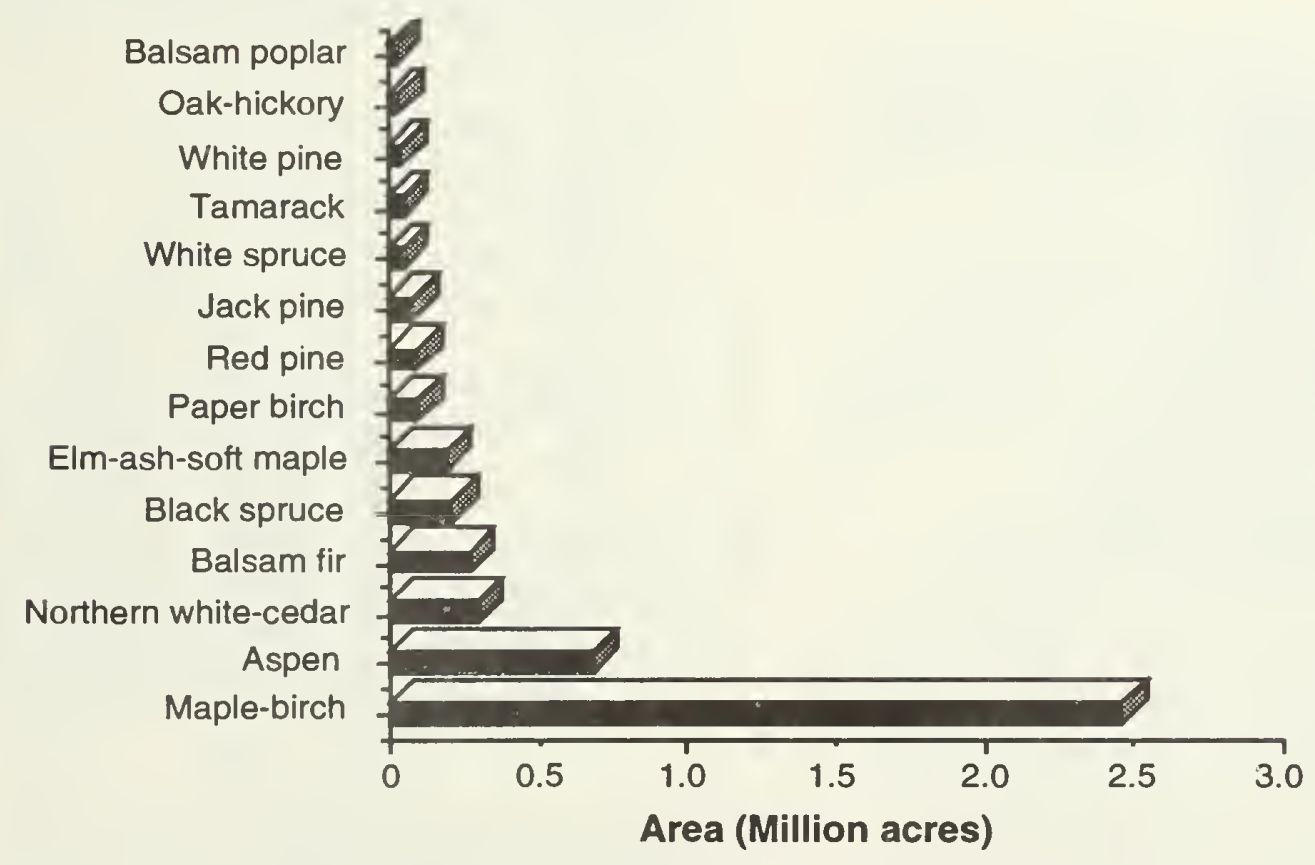

Figure 4.--Area of timberland by forest type, Western Upper Peninsula, 1993. 
- In 1993 sawtimber volume totaled 20.2 billion board feet, up one-third since 1980 when sawtimber volume was 15.2 billion board feet.

- Softwood growing-stock volume totaled 2.3 billion cubic feet in 1993. Fifty-nine percent ( 1.4 billion cubic feet) of this volume is in three species groups-hemlock, northern white-cedar, and balsam fir (fig. 6). Between inventories, the growing-stock volume of balsam fir declined by 2.8 percent, and the growing-stock volume of northern white-cedar and hemlock increased by 28 and 19 percent, respectively.

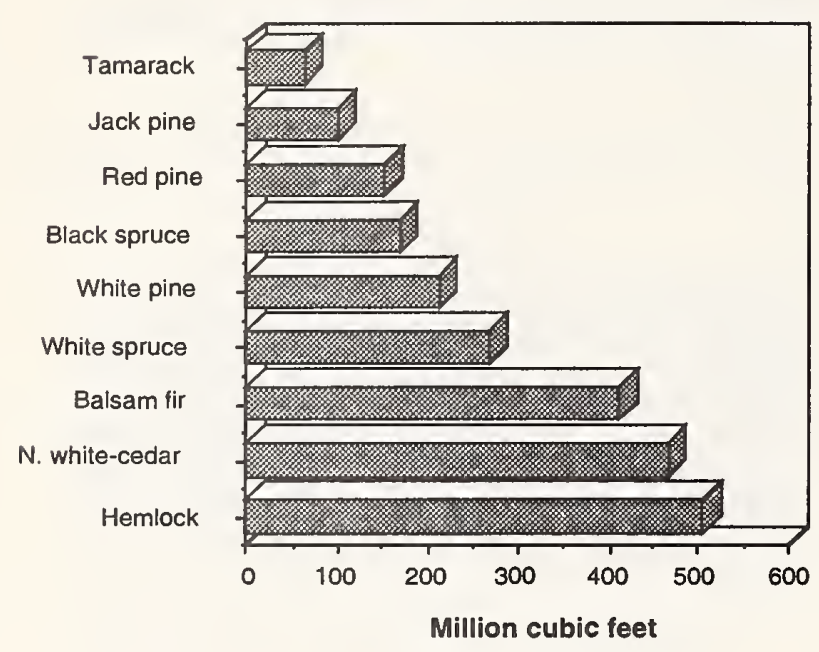

Figure 6.-Growing-stock volume for softwoods by major species groups, Western Upper Peninsula, 1993.

- Hardwood growing-stock volume totaled 5 billion cubic feet in 1993, an increase of 18 percent over 1980 . Fifty-seven percent $(2.8$ billion cubic feet) of hardwood growingstock volume is in maples (fig. 7).

- Hard maple, hemlock, and white pine accounted for 69 percent of the growingstock volume in trees over 21 inches in diameter, and this volume accounts for 4 percent of total growing-stock volume. These larger and generally older trees have aesthetic appeal not associated with smaller trees. Also, the larger trees and older stands provide wildlife food and cover not available in younger stands.

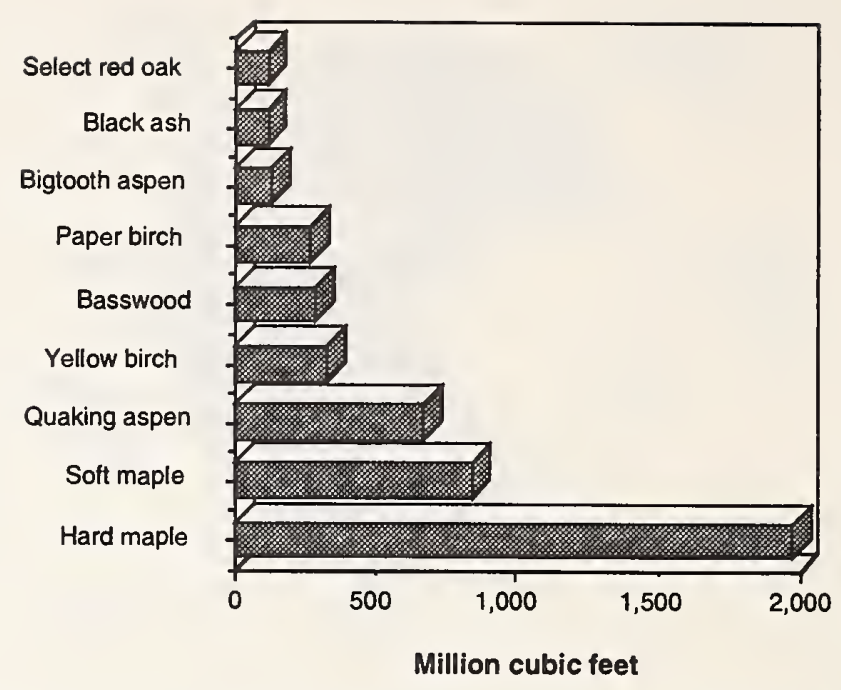

Figure 7.-Growing-stock volume for hardwoods by major species groups, Western Upper Peninsula, 1993.

- Growing-stock volume of all four major species groups increased from 1980 to 1993 (fig. 8). The greatest proportional increase was for pines, which increased by 29 percent, followed by an increase of 28 percent for hard hardwoods, 18 percent for other softwoods, and 9 percent for soft hardwoods.

- Between 1980 and 1993, growing-stock volume increased for all species groups except jack pine, balsam fir, select white oak, yellow birch, and elm. The volume of

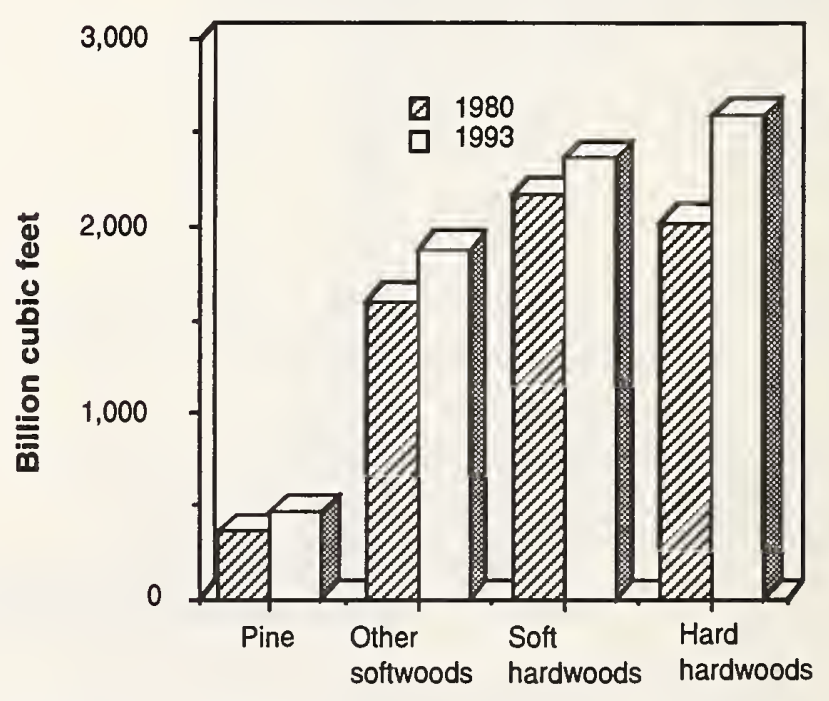

Figure 8.-Net volume of growing-stock by four major species groups, Western Upper Peninsula, 1993. 
elm declined by 109.4 million cubic feet (74 percent) as a result of the spread of Dutch elm disease during the years between inventories. The decline in the other species was more modest.

- Twenty-five percent of the growing-stock volume in the Unit is on forest industry timberland. Nonindustrial private owners hold 43 percent of the growing-stock volume. Thirty-two percent of the volume is on public timberland. The Ottawa National Forest administers 18 percent of the Unit's total volume and 29 percent of the Unit's pine volume.

- In addition to the 7.3 billion cubic feet of growing stock in the Unit, there are 940.8 million cubic feet in cull trees (rough and rotten) and in salvable dead trees.

- Hard maple accounted for 41 percent of all hardwood volume with a tree grade of one, best of the four tree grades used.

\section{TIMBER GROWTH, REMOVALS, AND MORTALITY}

\section{Growth}

- Average net annual growth of growing stock on timberland in the Western Upper Peninsula of Michigan was 167.8 million cubic feet during the period 1980 through 1992 .

- Softwoods accounted for 52 million cubic feet ( 31 percent) of the total average net annual growth of growing stock between 1980 and 1992. Hardwoods accounted for 115.7 million cubic feet (69 percent).

- Growing-stock average net annual growth between 1980 and 1992 was 2.3 percent of inventory.

- Sawtimber averaged 634.9 million board feet of net annual growth during the period 1980 through 1992. On average, every acre of timberland in the Unit grew about 138 board feet of sawtimber annually.

\section{Removals}

- Annual removals of growing stock from timberland averaged 82.5 million cubic feet from 1980 through 1992. Annual sawtimber removals averaged 268.6 million board feet between those years.

- More than half (58 percent) of the softwood sawtimber average annual removals was from three species-white pine ( 24 percent), hemlock ( 21 percent), and northern whitecedar (13 percent). Sixty percent of the sawtimber average annual removals from hardwoods was from hard maple (39 percent) and quaking aspen ( 21 percent).

- Timberland owned by forest industries accounted for one-third of the Unit's average annual removals of growing stock. Although many species were removed hard maple at 9.8 million cubic feet totaled 35 percent of all removals from timberland owned by forest industries. For the Ottawa National Forest, quaking aspen annual removals, at 4.4 million cubic feet, amounted to 35 percent of all removals from the Forest.

- Forest industry timberland accounted for 41 percent of all sawtimber annual removals between 1980 and 1992, followed by nonindustrial timberland owners with 39 percent of sawtimber average annual removals (fig. 9).

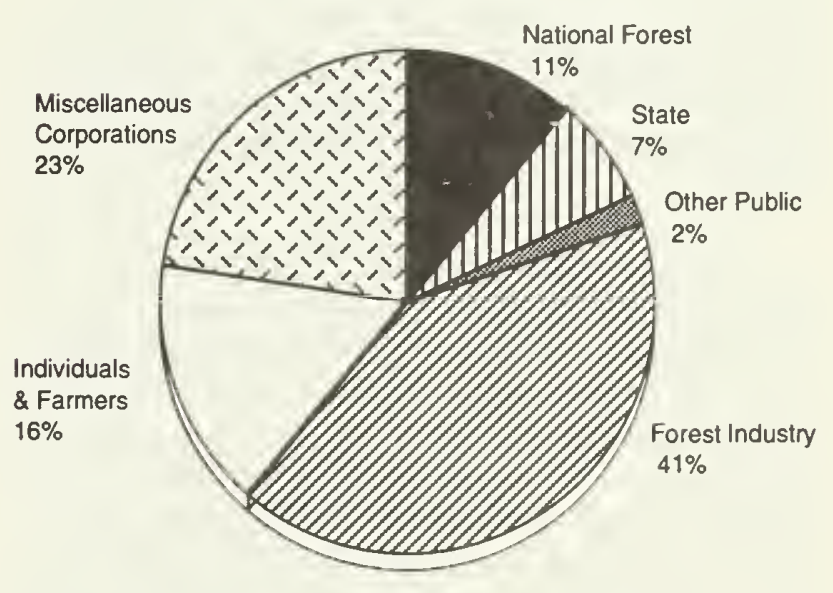

Figure 9.-Average annual removals of sawtimber on timberland by ownership class, Western Upper Peninsula, 1980-1992. 
- Annual growing-stock removals on timberland in the Western Upper Peninsula Unit averaged almost half (49 percent) of annual growing-stock growth from 1980 through 1992-82.5 million cubic feet of removals compared to 167.8 million cubic feet of growth.

- Annual growing-stock removals on timberland averaged 18 cubic feet per acre, representing slightly more than 1 percent of the total volume per acre.

\section{Mortality}

- Mortality of growing stock averaged 64 million cubic feet per year from 1980 through 1992. Sawtimber average annual mortality was 157.9 million board feet during the period.

- Balsam fir, aspen, and elm accounted for about half of the average growing-stock mortality volume between inventories. Wind damage in older stands and the spruce budworm and other insects caused mortality in balsam fir. Aspen is susceptible to many diseases, and much of the aspen mortality may be because many of the stands are beyond pathological rotation age. Most of the mortality in elm resulted from Dutch elm disease.

\section{APPENDIX}

\section{ACCURACY OF THE SURVEY}

Forest Inventory and Analysis (FIA) information is based on a sampling procedure designed to provide reliable statistics at the State and Survey Unit levels. Consequently, the reported figures are estimates only. A measure of reliability of these figures is given by sampling errors. The level of sampling error utilized by FIA means the chances are two out of three that if a 100-percent inventory had been taken, using the same methods, the results would have been within the limits indicated.

For example, the estimated growing-stock volume in the Western Upper Peninsula Unit in Michigan in 1993-7,297.7 million cubic feet-has a sampling error of \pm 1.05 percent $( \pm$ 76.6 million cubic feet). Based on this sampling error, growing-stock volume from a 100percent inventory would be expected to fall between 7,221.1 and 7,374.3 million cubic feet $(7,297.7 \pm 76.6)$, there being a one in three chance that this is not the case. The following tabulation shows the sampling errors for Michigan's Western Upper Peninsula Forest Inventory:

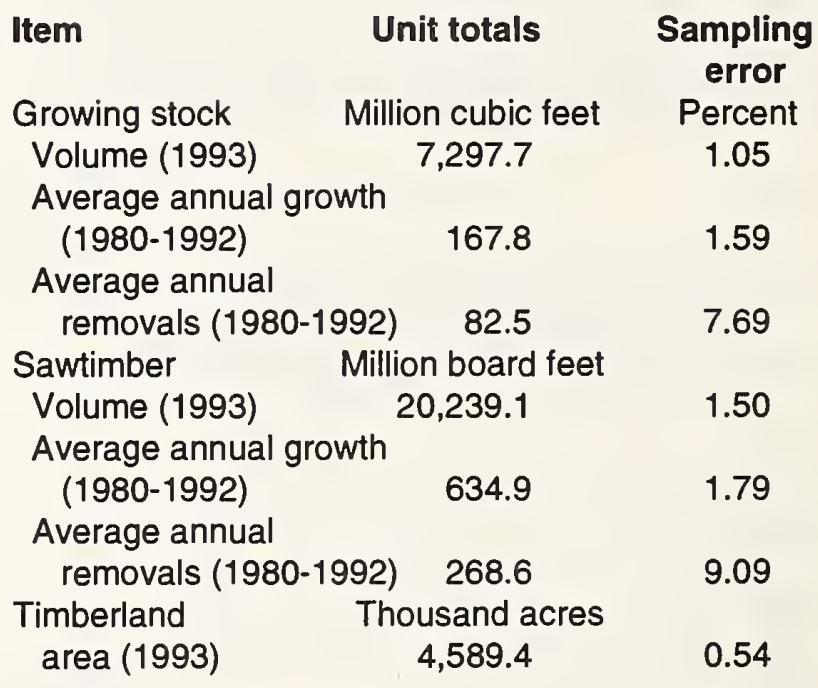

As survey data are broken down into sections smaller than Survey Unit totals, the sampling error increases. For example, the sampling error for timberland area in a particular county is higher than that for total timberland area in the Unit. This tabulation shows the sampling errors for Unit totals. To estimate sampling error for data smaller than Unit totals, use the following formula: 
$\mathbf{E}=$

\section{(SE) \\ (Unit total area or volume)}

$\sqrt{\text { (Volume or area smaller than Unit total) }}$

where:

$\mathrm{E}=$ sampling error in percent

$\mathrm{SE}=$ Unit total error for area or volume

For example, to compute the error on the area of timberland in the maple-birch type for the Unit, proceed as follows:

1. Total area of timberland in the maple-birch forest type in the Unit from table $3=2,464,500$ acres;

2. Total area of all timberland in the Unit from table $3=4,589,400$ acres;

3. Unit total error for timberland area from the above tabulation $=0.54$ percent.

Using the above formula:

$E=\frac{(0.54) \sqrt{(4,589,400)}}{\sqrt{(2,464,500)}}=0.74$ percent

\section{County Data}

A standard FLA inventory is designed to provide sampling errors of no more than 3 percent per million acres of timberland. Thus, this Unit's 4.589 million acres of timberland would require a sampling error of 1.40 percent to meet national FIA standards. The State of Michigan funded the collection of additional field data to substantially reduce this sampling error. The goal was to provide a sampling error of less than 10 percent for total timberland area by county. The sampling error within a county depends on county size and total area of timberland. To provide for a sampling error of less than 10 percent for total timberland area by county, a minimum acreage level of about 35,000 acres was required. The eight counties in the Western Upper Peninsula are heavily forested which, in combination with the intensified sample size provided by the Michigan Department of Natural Resources (MiDNR), resulted in sampling errors for each county of well below 5 percent.
COMPARING THE FIFTH INVENTORY OF THE WESTERN UPPER PENINSULA WITH THE FOURTH INVENTORY

A new volume estimation procedure was developed for the Lake States. We used this procedure to compute the 1993 volumes and to re-compute the 1980 volume for growth calculations. Although the adjustment will differ by species, the re-computed 1980 volumes will generally be greater than those shown in the original 1980 report.

Past surveys used only growing-stock trees to determine stand-size class. Current survey procedures require that stand-size class be determined on the basis of all live trees. Therefore, direct comparisons of current inventory data to old inventory data by standsize class may be misleading.

The basic building block for estimating forest area and timber volume has been changed from the Survey Unit (as utilized during the 1980 inventory) to the county (current methodology). In the past, statistics were developed at the Unit level and prorated back to the county on the basis of photo-interpretation results. Direct development of county-level data helps users interested in more precise local data, but can make the outcome of comparisons with past estimates uncertain.

\section{SURVEY PROCEDURES}

The 1993 survey of Michigan's Western Upper Peninsula used a growth model-enhanced, two-phase sample design. Using this sampling scheme and associated estimators is similar to sampling with partial replacement, in that a set of randomly located plots is available for remeasurement and a random set of new plots is established and measured. A significant feature of the new design is stratification for disturbance on the old sample and use of a growth model to improve regression estimates made on old undisturbed forest plots (fig. 10). Detailed descriptions of the sampling and estimation procedures are presented by Hansen (1990). The growth model used in the survey design for Michigan's Western Upper Peninsula was the Lake States Stand and Tree Evaluation and Modeling System (STEMS) (Belcher et al. 1982). 


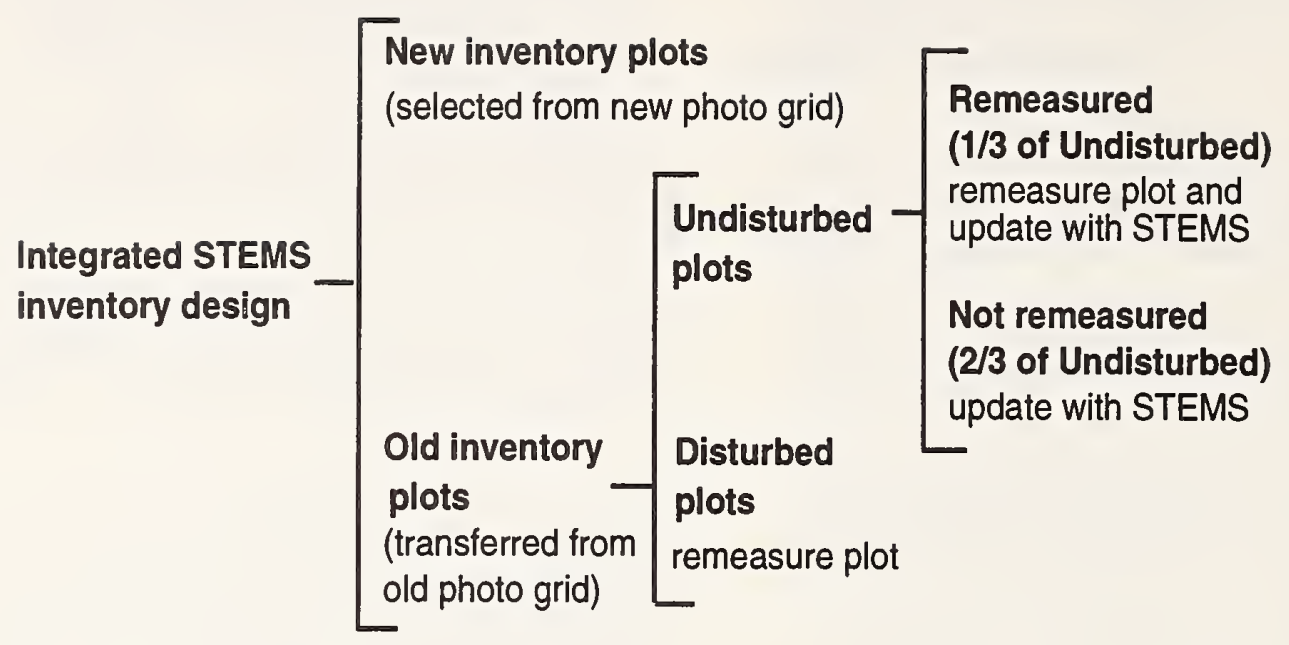

Figure 10.-Overview of the sample design for theWestern Upper Peninsula 1993 survey.

\section{Major Steps in the New Survey Design}

1. Aerial photography (Phase 1)

In this phase, two sets of random points were located on current aerial photographs. The first set was new photo plots, and the second set was relocated, old ground plot locations from the 1980 inventory. Locations of the plots used in the 1980 inventory were transferred to the new photographs. The photographs were then assembled into township mosaics, and a systematic grid of 121 one-acre photo plots (each plot representing approximately 190.4 acres) was overlaid on each township mosaic. Each photo plot was examined by aerial photogrammetrists and classified stereoscopically as to its land use. If trees were present, forest type and stand-size/ density classes were recorded. All of the 1980 ground plot locations were also examined for disturbance (logging, fire, catastrophic mortality, etc.). After this examination, all the old "disturbed" sample locations and one-third of the old "undisturbed" forested plots were sent to the field for survey crews to verify the photo classification and to take further measurements. All photo plot locations for the 1993 inventory were examined and classified as shown in the following tabulation:

$\begin{array}{lr}\text { Photo land class } & \text { Photo plots } \\ \text { Timberland } & 23,835 \\ \text { Reserved forest land } & 1,204 \\ \text { Other forest land } & 36 \\ \text { Questionable } & 522 \\ \text { Nonforest with trees } & 561 \\ \text { Nonforest without trees } & 2,747 \\ \text { Water } & 977 \\ \text { All classes } & 29,882\end{array}$

2. Plot measurements (Phase 2)

On plots classified as timberland, wooded pasture, or windbreak (at least 120 feet wide), a ground plot was established, remeasured, or modeled. Old plots sent to the field for remeasurement that could not be relocated were replaced with a new plot at the approximate location of the old one. Each ground plot consisted of a 10-point cluster covering 1 acre. At each point, trees 5.0 inches or more d.b.h. were sampled on a $\mathbf{3 7 . 5}$ basal area factor variable-radius plot, and trees less than 5.0 inches d.b.h. were sampled on a 1/300-acre fixed-radius plot. The measurement procedure for both the new and old sample locations was as follows:

\section{a. New inventory plots}

A random sample of the new photo plots was selected for field measurement. Ground plots 
were established, and measures of current classification such as land use, forest type, and ownership, as well as size and condition of all trees on the plot were recorded. These locations were monumented for future remeasurement.

\section{b. Old inventory plots}

These plots were originally established, monumented, and measured as part of the 1980 field inventory. Procedures for these old plots were different from those for the new plots. Old plots were classed as "undisturbed" or "disturbed" in the aerial photo phase of the sampling process. All disturbed plots, and a one-third sample of the undisturbed forested plots, were remeasured to obtain estimates of current condition and changes since the last inventory. All trees measured on these plots in 1980 were remeasured or otherwise accounted for, and all new trees were identified and measured.

All sample plots that were forested at the time of the 1980 inventory and determined to be undisturbed until the 1993 inventory were projected to the current time (1993) using STEMS. This procedure gives projected estimates of current volume and growth for undisturbed plots. Comparison of the projected and observed values on the one-third sample of the undisturbed forest plots that were remeasured provided local calibration data to adjust the projected values of the undisturbed plots that were not remeasured. The adjustment procedure is a modified version of the method described by Smith (1983).
Undisturbed forested plots that were not remeasured played a crucial role in the new survey design. These plots, after careful comparison of past and current aerial photography, were determined to be undisturbed and had conditions that could be simulated by STEMS. The STEMS growth model was used to "grow" the old plot and tree data to produce an estimate of current data. Thus, these plots were treated as ground plots, even though they were never visited. The plot record for each modeled plot was sent to the field for verification of current ownership information.

All old plots classified as disturbed were sent to the field for remeasurement to assess and verify changes since the last inventory. Disturbance referred to any change on a plot that was detected on aerial photos and that the STEMS growth processor could not predict, such as catastrophic mortality, cutting, seedling stands, and/or land use change.

The estimation procedure for computing statistics from this sampling design was more complicated than the simple two-phase estimation procedure used in the past. In fact, this procedure yielded two independent samples, one coming from the new photo points and the other from the old photo points that were remeasured or modeled. The following tabulation summarizes the distribution of all ground plots for the new inventory design by type of plot:

\section{Ground land use class}

Timberland

Reserved forest land

Other forest land

Nonforest with trees

Nonforest without trees

Water

Total

\begin{tabular}{rrrr}
$\begin{array}{c}\text { Old plots } \\
\text { remeasured }\end{array}$ & $\begin{array}{c}\text { Old plots } \\
\text { updated }\end{array}$ & $\begin{array}{l}\text { New } \\
\text { plots }\end{array}$ & $\begin{array}{c}\text { Total } \\
\text { plots }\end{array}$ \\
1,074 & 1,434 & 657 & 3,165 \\
7 & 10 & 243 & 260 \\
12 & 0 & 3 & 15 \\
34 & 14 & 13 & 61 \\
59 & 213 & 92 & 364 \\
16 & 81 & 32 & 129 \\
\hline 1,202 & 1,752 & 1,040 & 3,994
\end{tabular}




\section{Area estimates}

Area estimates were made using two-phase estimation methods. In this type of estimation, a preliminary estimate of area by land use is made from the aerial photographs (Phase 1) and corrected by the plot measurements (Phase 2). A complete description of this estimation method is presented by Loetsch and Haller (1964). All area estimates were based on what existed as of January 1 , 1993, in the Western Upper Peninsula of Michigan.

\section{Volume estimates}

Estimates of volume per acre were made from the trees measured or modeled on the 10-point plots. Estimates of volume per acre were multiplied by the area estimates to obtain estimates of total volume. Volume estimates were based on what existed as of January 1 . 1993, in the Western Upper Peninsula of Michigan. Net cubic foot volumes were based on a modification of the method presented by Hahn (1984) for use in the Lake States. For the Western Upper Peninsula inventory, the merchantable height equation presented was used in conjunction with Hahn's Board Foot Volume Equation (adapted from Stone's equation, Hahn 1984) to estimate gross volume. This estimate was then corrected by species for variation in bark and cull volume to yield an estimate of net volume (Hahn 1984).

The Forest Service reports all board foot volume in International $1 / 4$-inch rule. In Michigan, the Scribner log rule is commonly used. Scribner log rule conversion factors were derived from full tree measurements taken throughout the Lake States (Michigan, Wisconsin, and Minnesota) and an equation developed by Wiant and Castenaeda (1977). Factors, or multipliers, that can be used to convert board foot International volumes to the Scribner rule are shown in the following tabulation:
D.b.h. (inches)

\section{Scribner rule conversion factor} Softwoods Hardwoods

$\begin{array}{ccc}9.0-10.9 & 0.7830 & - \\ 11.0-12.9 & 0.8287 & 0.8317 \\ 13.0-14.9 & 0.8577 & 0.8611 \\ 15.0-16.9 & 0.8784 & 0.8827 \\ 17.0-18.9 & 0.8945 & 0.8999 \\ 19.0-20.9 & 0.9079 & 0.9132 \\ 21.0-22.9 & 0.9168 & 0.9239 \\ 23.0-24.9 & 0.9240 & 0.9325 \\ 25.0-26.9 & 0.9299 & 0.9396 \\ 27.0-28.9 & 0.9321 & 0.9454 \\ 29.0+ & 0.9357 & 0.9544\end{array}$

\section{Growth and mortality estimates}

On remeasured plots, estimates of growth and mortality per acre come from the remeasured diameters of trees and from observation of trees that died between inventories. Growth reported as the average net annual growth between the two inventories (1980 and 1992) was computed from data on remeasurement plots and modeled plots using methods presented by VanDeusen et al. (1986). Mortality was also reported as average annual for the remeasurement period. On new plots, where trees were not remeasured, estimates of growth and mortality were obtained by using STEMS to project the growth and mortality of trees for 1 year. Growth and mortality estimates for old undisturbed plots that were updated were derived in the same manner as remeasured plots. The STEMS growth model was adjusted to meet local conditions, using data from the undisturbed remeasurement plots. As with volume, total growth and mortality estimates were obtained by multiplying the per acre estimates by area estimates. Current annual growth for 1992 was computed by using the adjusted STEMS model to grow all current inventory plots for 1 year. All growth and mortality estimates were based on growth and mortality through December 31 , 1992 , in the Western Upper Peninsula of Michigan.

\section{Average annual removals estimates}

Average annual growing-stock and sawtimber removals (1980 to 1992) were estimated only from the remeasured plots; new plots were not used to estimate removals. These estimates are obtained from trees measured in the last survey and cut or otherwise removed from the timberland base. All removal estimates were 
based on removals through December 31 , 1992, in the Western Upper Peninsula of Michigan. Because remeasurement plots make up about one-half of the total ground plots, average annual removals estimates have greater sampling errors than volume and growth estimates.

\section{Tree and Log Grades}

On approximately one-third of the sample plots in Michigan's Western Upper Peninsula, all sawtimber sample trees were graded for quality and assigned either a tree grade (hardwoods) or a log grade (softwoods). Tree and log grades were based on the evaluation of external characteristics as indicators of quality. The volume yield by grade for this sample was used to distribute the volume of the ungraded sample trees by species group. Hardwood sawtimber trees were graded according to "Hardwood tree grades for factory lumber" (Hanks 1976). The best 12-foot section of the lowest 16-foot hardwood log was used for grading. Hardwood sawtimber trees that did not meet minimum tree grade specifications for grades 1 through 3 were assigned grade 4 according to Forest Service standard specifications for hardwood construction logs described in "A guide to hardwood log grading" (Rast et al. 1973). Red pine and jack pine sawtimber trees were graded based on specifications described in "Forest Service log grades for southern pines" (Campbell 1964). White pine and other softwood sawtimber trees were graded according to specifications described in the circular "Log grades" (Peterson 1965). For all softwoods, the first merchantable 16-foot $\log$, or shorter lengths down to 12 feet, was used for grading.

\section{Hardwood Tree Grades for Factory Lumber}

\begin{tabular}{|c|c|c|c|c|c|c|}
\hline Grade factor & \multicolumn{3}{|c|}{$\begin{array}{c}\text { Tree grade } \\
1\end{array}$} & \multicolumn{2}{|c|}{ Tree grade } & $\begin{array}{c}\text { Tree grade } \\
\mathbf{3}\end{array}$ \\
\hline Length of grading zone (feet) & \multicolumn{3}{|c|}{ Butt 16} & \multicolumn{2}{|c|}{ Butt 16} & Butt 16 \\
\hline $\begin{array}{l}\text { Length of grading section a } \\
\text { (feet) }\end{array}$ & \multicolumn{3}{|c|}{ Best 12} & \multicolumn{2}{|c|}{ Best 12} & Best 12 \\
\hline D.b.h., minimum (inches) & \multicolumn{3}{|c|}{$16^{\mathrm{b}}$} & \multicolumn{2}{|c|}{13} & 11 \\
\hline $\begin{array}{l}\text { Diameter, minimum inside bark } \\
\text { at top of grading section } \\
\text { (inches) }\end{array}$ & $13^{\mathrm{k}}$ & 16 & 20 & $11^{\mathrm{c}}$ & 12 & 8 \\
\hline \multicolumn{7}{|l|}{$\begin{array}{l}\text { Clear cuttings (on the three } \\
\text { best faces): } \mathrm{d}\end{array}$} \\
\hline $\begin{array}{l}\text { Length, minimum (feet) } \\
\text { Number on face (maximum) }\end{array}$ & 7 & $\begin{array}{l}5 \\
2\end{array}$ & 3 & & $\begin{array}{l}3 \\
3\end{array}$ & $\begin{array}{l}2 \\
\mathrm{e}\end{array}$ \\
\hline $\begin{array}{l}\text { Yield in face length } \\
\text { (minimum) }\end{array}$ & \multicolumn{3}{|c|}{$5 / 6$} & \multicolumn{2}{|c|}{$4 / 6$} & $3 / 6$ \\
\hline $\begin{array}{l}\text { Cull deduction (including crook } \\
\text { and sweep, but excluding } \\
\text { shake) maximum within } \\
\text { grading section (percent) }\end{array}$ & \multicolumn{3}{|c|}{9} & \multicolumn{2}{|c|}{$9^{f}$} & 50 \\
\hline
\end{tabular}

a Whenever a 14- or 16-foot section of the butt 16-foot log is better than the best 12-foot section, the grade of the longer section will become the grade of the tree. This longer section, when used, is the basis for determining the grading factors.

b In basswood and ash, diameter inside bark (d.i.b.) at top of grading section must be 12 inches and d.b.h. must be 15 inches.

c Grade 2 trees can be 10 inches d.i.b. at top of grading section if otherwise meeting surface requirements for small grade 1's.

d A clear cutting is a portion of a face free of defects, extending the width of the face. A face is onefourth of the surface of the grading section as divided lengthwise.

e Unlimited.

f Fifteen percent crook and sweep or 40 percent total cull deduction are permitted in grade 2, if size and surface of grading section qualify as grade 1 . If rot shortens the required clear cuttings to the extent of dropping the butt log to grade 2, do not drop the tree's grade to 3 unless the cull deduction for rot is greater than 40 percent. 


\section{Forest Service Standard Specifications for Hardwood Construction Logs(tie and timber logs) a}

\begin{tabular}{l|l}
\hline Position in tree & Butts and uppers \\
\hline Min. diameter, small end & 8 inches + \\
\hline Min. length without trim & 8 feet + \\
\hline Clear cuttings & No requirements \\
\hline Sweep allowance & $\begin{array}{l}\text { One-fourth small end d.i.b. for each 8 feet of } \\
\text { length. One-half d.i.b. for logs 16 feet long. }\end{array}$ \\
\hline Sound surface defects: & \\
\hline Single knots & $\begin{array}{l}\text { Any number, if no knot has an average diameter } \\
\text { above the callus in excess of one-third of the log } \\
\text { diameter at point of occurrence. }\end{array}$ \\
\hline Whorled knots & $\begin{array}{l}\text { Any number, if the sum of knot diameters above } \\
\text { the callus does not exceed one-third of the log } \\
\text { diameter at point of occurrence. }\end{array}$ \\
\hline Holes & $\begin{array}{l}\text { Any number not exceeding knot specifications as } \\
\text { long as they do not extend over 3 inches into } \\
\text { contained tie or timber. }\end{array}$ \\
\hline Unsound defects : & $\begin{array}{l}\text { Same requirements as for sound defects if they } \\
\text { extend into included timber. No limit if they do } \\
\text { not. }\end{array}$ \\
\hline Surface & $\begin{array}{l}\text { None permitted except one shake not more than } \\
\text { one-third the width of contained tie or timber, } \\
\text { and one split, not over 5 inches. }\end{array}$ \\
\hline Interior
\end{tabular}

a These specifications are minimum for the class. If, from a group of logs, factory logs are selected first, thus leaving only nonfactory logs from which to select construction logs, then the quality range of the construction logs so selected is limited, and the class may be considered a grade. If selection for construction logs is given first priority, it may be necessary to subdivide the class into grades.

\section{Log Grades for Jack Pine and Red Pine}

Grade 1: Logs with three or four clear faces on the 16-foot grading section. ${ }^{\text {a }}$

Grade 2: Logs with one or two clear faces on the 16-foot grading section.

Grade 3: Logs with no clear faces on the 16 -foot grading section.

After the tentative grade is established from above, the log will be reduced one grade for each of the following defects, except that no log can be reduced below grade 3 . Net scale after deduction for defect must be at least 50 percent of the gross contents of the $\log$.

1. Sweep. Degrade any tentative grade 1 or $2 \log$ one grade if sweep amounts to 3 or more inches and equals or exceeds one-third of the diameter inside bark at the small end.

2. Heart rot. Degrade any tentative grade 1 or 2 log one grade if conk, punk knots, massed hyphae, or other evidence of advanced heart rot is found anywhere on the log.

a A face is one-fourth of the circumference in width extending full length of the log. Clear faces are those free of: knots measuring more than 1/2-inch in diameter, overgrown knots of any size, and holes more than $1 / 4$-inch in diameter. Faces may be rotated to obtain the maximum number of clear ones. 
Eastern White Pine Saw log Grade Specifications

Grading Factor Log Grade 1

Log Grade 2

Log Grade 3

Log Grade 4

1. Minimum

$14^{a}$

6

6

6

Scaling Diameter (inches)

2. Minimum

$10^{b}$

8

8

8

Log Length (feet)

3. Maximum

None

None

2 Injuries $c$

No Limit

Weevil Injury (number)

4. Minimum

Face

Requirements

four $50 \% \mathrm{~d}$ length

good faces (in length

addition, log knots

on balance of faces

shall not exceed

size limits of grade

2 logs.

or NO GOOD FAC
Maximum diameter of
three best faces:
SOUND RED KNOTS
not to exceed $1 / 6$ scaling
diameter and
3 inch maximum.
DEAD OR BLACK
KNOTS including
overgrown knots
not to exceed $1 / 12$
scaling diameter
and 1-1/2 inch
maximum.

Includes all logs not qualifying for No. 3 or better and have at least $1 / 3$ of their gross volume in sound wood suitable for manufacture into standard lumber.
SOUND RED Knots

scaling diameter and

5 inch maximum.

DEAD OR BLACK

KNOTS including

overgrown knots

not to exceed $1 / 6$

scaling diameter

and 2-1/2 inch maximum.

5. Maximum sweep or crook allowance (\%)

20. 30 40 $662 / 3$

\section{Maximum} total scaling deduction (\%) $\quad 50$ 50 50 $662 / 3$

\section{AFTER THE TENTATIVE LOG GRADE IS ESTABLISHED FROM FACE EXAMINATION, THE LOG WILL BE REDUCED IN GRADE WHENEVER THE FOLLOWING DEFECTS ARE EVIDENT.}

7. Conks, punk knots, and pine borer damage on bark surface ${ }^{\mathrm{e}}$.

Degrade one grade if present on one face.

Degrade two grades if present on two faces.

Degrade three grades if present on three or more faces.

8. Log end defects: red rot, ring shake, heavy stain and pine borer damage outside the heart center of $\log$.

Consider log as having a total of 8 quarters ( 4 on each end) and degrade as indicated.

Degrade one grade if present in 2 quarters of log ends.

Degrade two grades if present in 3 or 4 quarters of log ends.

Degrade three grades if present in 5 or more quarters of log ends.

a. Twelve- and thirteen-inch logs with four full length good faces are acceptable.

b. $\quad$ Eight-foot logs with four full length good faces are acceptable.

c. $\quad$ Eight-foot Number 3 logs limited to one weevil injury.

d. Minimum 50\% length good face must be at least 6 feet.

e. Factors 7 and 8 are not cumulative (total degrade based on more serious of the two). No log is to be degraded below grade 4 if net scale is at least one-third of gross scale. 


\section{Log Grades for All Other Softwood Logs}

Grade 1

1. Trees must be 16 inches d.i.b. or larger, 10 feet in length or longer, and with deduction for defect, not over 30 percent of gross scale.

2. Logs must be at least 75 percent clear on each of three faces.

3. All knots outside clear cutting must be sound and not more than 2-1/2 inches in size.

Grade 2

1. Logs must be 12 inches d.i.b. or larger, 10 feet in length or longer, and with a net scale after deduction for defect of at least 50 percent of the gross contents of the log.

2. Logs must be at least 50 percent clear on each of three faces or 75 percent clear on two faces.

Grade 3

1. Logs must be 6 inches d.i.b. or larger, 8 feet in length or longer, and with a net scale after deduction for defect of at least 50 percent of the gross contents of the log.

Note: Diameters are d.i.b. at small end of grading section, and percent clear refers to percent clear in one continuous section.

\section{METRIC EGUIVALENTS OF UNITS USED IN THIS REPORT}

1 acre $=4,046.86$ square meters or 0.405 hectare.

1,000 acres $=405$ hectares.

1 cubic foot $=0.0283$ cubic meter.

1 foot $=30.48$ centimeters or 0.3048 meter.

1 inch $=25.4$ millimeters, 2.54 centimeters, or 0.0254 meter.

1 pound $=0.454$ kilogram .

1 ton $=0.907$ metric ton .

\section{TREE SPECIES GROUPS IN MICHIGAN'S WESTERN UPPER PENINSULA}

Species names are based on Little, 1981.

\section{SOFTWOODS}

Balsam fir Abies balsamea

Tamarack Larix laricina

White spruce Picea glauca

Black spruce Picea mariana

Jack pine... Pinus banksiana

Red pine Pinus resinosa

Eastern white pine Pinus strobus

Northern white-cedar Thuja occidentalis

Eastern hemlock

Other softwoods:

Engelmann spruce

Eastern redcedar

Scotch pine

\section{HARDWOODS}

Hard maple ${ }^{1}$

Sugar maple

Acer saccharum
Soft maple ${ }^{2}$

Red maple Acer rubrum

Silver maple

Birch

Yellow birch ${ }^{1}$

River birch ${ }^{2}$

Paper birch ${ }^{2}$................... Betula papyrifera

............Betula alleghaniensis

Bitternut hickory ${ }^{1}$............... Carya cordiformis

Hackberry Celtis occidentalis

Persimmon Diospyros virginiana

American beech

Ash

White ash ${ }^{1}$

Black ash ${ }^{2}$

Green ash ${ }^{1}$

Butternut ${ }^{2}$ Fagus grandifolia

Black walnut ${ }^{1}$

White poplar

Fraxinus americana

Balsam poplar Fraxinus nigra

Cottonwood

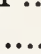

Bigtooth aspen ${ }^{2}$

Quaking aspen ${ }^{2}$

Black cherry Fraxinus pennsylvanica Juglans nigra Populus alba Select white oaks ${ }^{1}$

White oak Quercus alba

Swamp white oak Quercus bicolor

Bur oak

Select red oaks ${ }^{1}$

Northern red oak Quercus rubra

${ }^{1}$ This species or species group is considered a hard hardwood, with an average specific gravity greater than or equal to 0.50 .

2 This species or species group is considered a soft hardwood, with an average specific gravity of less than 0.50 . 
Other red oak

Northern pin oak

Quercus ellipsoidalis

Pin oak

Quercus palustris

American basswood Tilia americana

Elm

Winged elm ${ }^{2}$

Ulmus alata

American elm ${ }^{2}$ Ulmus americana

Slippery $\mathrm{elm}^{2}$ Ulmus rubra

Rock elm ${ }^{1}$ Ulmus thomasii

Other hardwoods

Boxelder Acer negundo

Ohio Buckeye Aesculus glabra

Sweet birch Betula lenta

Northern catalpa Catalpa speciosa Noncommercial species

Striped maple Acer pennsylvanicum Mountain maple Acer spicatum American hornbeam ........ Carpinus caroliniana Hawthorn Crataegus spp. Apple Malus spp. Eastern hophornbeam Ostrya virginiana Canada plum Prunus nigra Pin cherry Wild plum Prunus pensylvanica Chokecherry ..Prunus spp. Peachleaf willow .............. Salix amygdaloides Black willow............................... Salix nigra Willow spp. Salix spp.

\section{DEFINITION OF TERMS}

\section{Average annual removals from growing} stock.-The average net growing-stock volume in growing-stock trees removed annually for forest products (including roundwood products and logging residues) and for other uses (see Other removals). Average annual removals of growing stock are reported for a period of several years (1980 to 1993 in this report) and are based on information obtained from remeasurement plots (see Survey Procedures in Appendix).

\section{Average annual removals from sawtimber.-}

The average net board foot sawtimber volume of live sawtimber trees removed annually for forest products (including roundwood products and other uses [see Other removals]). Average annual removals of sawtimber are reported for a period of several years (1980 to 1993 in this report) and are based on information obtained from remeasurement plots (see Survey Procedures in Appendix).

\section{Average net annual growth of growing} stock.-The annual change in volume of sound wood in live sawtimber and poletimber trees and the total volume of trees entering these classes through ingrowth, less volume losses resulting from natural causes.

\section{Average net annual growth of sawtimber.-} The annual change in the volume of live sawtimber trees and the total volume of trees reaching sawtimber size, less volume losses resulting from natural causes.

Basal area.-Tree area in square feet of the cross section at breast height of a single tree. When the basal areas of all trees in a stand are summed, the result is usually expressed as square feet of basal area per acre.

Butt log.-The first 12 to 16 feet from a 1 -foot stump that could be, or is, cut. Minimum standards for butt logs vary by species.

Clear panel.-A section of hardwood tree surface one-fourth the circumference of the tree and at least 2 feet long, free of limbs, knots, bumps, and other indications of defect that preclude clear cuttings.

Commercial species.-Tree species presently or prospectively suitable for industrial wood products. (Note: Excludes species of typically small size, poor form, or inferior quality such as hophornbeam, osage-orange, and redbud.)

County and municipal land.-Land owned by counties and local public agencies or municipalities, or land leased to these governmental units for 50 years or more.

Cropland.-Land under cultivation within the past 24 months; including cropland harvested, crop failures, cultivated summer fallow, idle cropland used only for pasture, orchards, and land in soil improvement crops, but excluding land cultivated in developing improved pasture.

Cull.-Portions of a tree that are unusable for industrial wood products because of rot, missing or dead material, or other defect. 
Diameter class. - A classification of trees based on diameter outside bark, measured at breast height (d.b.h.). Two-inch diameter classes are commonly used in Forest Inventory and Analysis, with the even inch the approximate midpoint for a class. For example, the 6 -inch class includes trees 5.0 through 6.9 inches d.b.h.

\section{Diameter at breast height (d.b.h.).-The} outside bark diameter at 4.5 feet $(1.37 \mathrm{~m})$ above the forest floor on the uphill side of the tree. For determining breast height, the forest floor includes the duff layer that may be present, but does not include unincorporated woody debris that may rise above the ground line.

Face.-A section of the tree surface one-fourth the circumference of the tree extending the full length of the log.

Farm.-Any place from which $\$ 1,000$ or more worth of agricultural products were produced and sold during the year.

Farmer-owned land.-Land owned by farm operators whether part of the farmstead or not. (Note: Excludes land leased by farm operators from nonfarm owners, such as railroad companies and States.)

Forest industry land.-Land owned by companies or individuals operating wood-using plants.

Forest land.-Land at least 16.7 percent stocked by forest trees of any size, or formerly having had such tree cover, and not currently developed for nonforest use. (Note: Stocking is measured by comparing specified standards with basal area and/or number of trees, age or size, and spacing.) The minimum area for classification of forest land is 1 acre. Roadside, streamside, and shelterbelt strips of timber must have a crown width of at least 120 feet to qualify as forest land. Unimproved roads and trails, streams, or other bodies of water or clearings in forest areas shall be classed as forest if less than 120 feet wide. (See definitions for Land, Timberland, Reserved forest land, Other forest land, Stocking, and Water.)

Forest type.-A classification of forest land based on the species forming a plurality of live tree stocking. Major forest types in the State are:

Jack pine.-Forests in which jack pine comprises a plurality of the stocking. (Common associates include eastern white pine, red pine, aspen, birch, and maple.)

Red pine.-Forests in which red pine comprises a plurality of the stocking. (Common associates include eastern white pine, jack pine, aspen, birch, and maple.)

Eastern white pine.-Forests in which eastern white pine comprises a plurality of the stocking. (Common associates include red pine, jack pine, aspen, birch, and maple.)

Balsam fir.-Forests in which balsam fir and white spruce comprise a plurality of stocking with balsam fir the most common. (Common associates include white spruce, aspen, maple, birch, northern white-cedar. and tamarack.)

White spruce.-Forests in which white spruce and balsam fir comprise a plurality of the stocking with white spruce the most common. (Common associates include balsam fir, aspen, maple, birch, northern white-cedar, and tamarack.)

Black spruce.-Forests in which swamp conifers comprise a plurality of the stocking with black spruce the most common. (Common associates include tamarack and northern white-cedar.)

Northern white-cedar.-Forests in which swamp conifer species comprise a plurality of the stocking with northern white-cedar the most common. (Common associates include tamarack and black spruce.)

Tamarack.-Forests in which swamp conifers comprise a plurality of the stocking with tamarack the most common. (Common associates include black spruce and northern white-cedar.)

Oak-hickory.-Forests in which northern red oak, white oak, bur oak, or hickories, singly or in combination, comprise a plurality of the stocking. (Common associates include jack pine, beech, yellow-poplar, elm, and maple.)

Elm-ash-soft maple.-Forests in which lowland elm, ash, red maple, silver maple, and cottonwood, singly or in combination, comprise a plurality of the stocking. (Common associates include birch, spruce, and balsam fir.)

Maple-birch.-Forests in which sugar maple, basswood, yellow birch, upland 
American elm, and red maple, singly or in combination, comprise a plurality of the stocking. (Common associates include birch, spruce, and balsam fir.)

Aspen.-Forests in which quaking aspen or bigtooth aspen, singly or in combination, comprise a plurality of the stocking. (Common associates include balsam poplar,

balsam fir, and paper birch.)

Paper birch.Forests in which paper birch comprises a plurality of the stocking. (Common associates include maple, aspen, and balsam fir.)

Balsam poplar.-Forests in which balsam poplar comprises a plurality of the stocking. (Common associates include aspen, elm, and ash.)

Growing-stock tree.-A live tree of commercial species that meets specified standards of size, quality, and merchantability. (Note: Excludes rough, rotten, and dead trees.)

Growing-stock volume.-Net volume in cubic feet of growing-stock trees 5.0 inches d.b.h. and over, from 1 foot above the ground to a minimum 4.0 inch top diameter (outside bark) of the central stem or to the point where the central stem breaks into limbs.

Hard hardwoods.- Hardwood species with an average specific gravity greater than 0.50 such as oaks, hard maple, and hickories.

Hardwoods.-Dicotyledonous trees, usually broad-leaved and deciduous (see Soft hardwoods and Hard hardwoods.)

Improved pasture.-Land currently improved for grazing by cultivation, seeding, irrigation, or clearing of trees and brush.

Indian owned land.-Land held in trust by the United States for tribes or individual Native Americans.

Industrial wood.-All roundwood products except residential fuelwood.

Land.-A. Bureau of the Census. Dry land and land temporarily or partly covered by water such as marshes, swamps, and river flood plains (omitting tidal flats below mean high tide); streams, sloughs, estuaries, and canals less than one-eighth of a statute mile wide; and lakes, reservoirs, and ponds less than 40 acres in area.
B. Forest Inventory and Analysis. The same as the Bureau of the Census, except minimum width of streams, etc., is 120 feet and minimum size of lakes, etc., is less than 1 acre.

Live trees.-Growing-stock, rough, and rotten trees 1.0 inch d.b.h. and larger.

Log grade.-A log classification based on external characteristics as indicators of quality or value. (See Appendix for specific grading factors used.)

Marsh.-Nonforest land that characteristically supports low, generally herbaceous or shrubby vegetation and that is intermittently covered with water.

Merchantable.-Refers to a pulpwood or sawlog section that meets pulpwood or saw-log specifications, respectively.

Miscellaneous Federal land.-Federal land other than National Forest and land administered by the Bureau of Land Management or Bureau of Indian Affairs.

Miscellaneous private land.-Privately owned land other than forest-industry and farmerowned land.

Mortality.-The volume of sound wood in growing-stock and sawtimber trees that die annually.

National Forest land.-Federal land that has been legally designated as National Forest or purchase units, and other land administered by the USDA Forest Service.

Net volume.-Gross volume less deductions for rot, sweep, or other defect affecting use for timber products.

Noncommercial species.-Tree species of typically small size, poor form, or inferior quality that normally do not develop into trees suitable for industrial wood products.

Nonforest land.-Land that has never supported forests, and land formerly forested where use for timber management is precluded by development for other uses. (Note: Includes areas used for crops, improved pasture, residential areas, city parks, improved roads of any width and adjoining 
clearings, powerline clearings of any width, and 1- to 40-acre areas of water classified by the Bureau of the Census as land. If intermingled in forest areas, unimproved roads and nonforest strips must be more than 120 feet wide and more than 1 acre in area to qualify as nonforest land.)

a. Nonforest land without trees.-Nonforest land with no live trees present.

b. Nonforest land with trees.-Nonforest land with one or more trees per acre at least 5 inches d.b.h..

Nonstocked land.-Forest land less than 16.7 percent stocked with all live trees.

Other forest land.-Forest land not capable of producing 20 cubic feet per acre per year of industrial wood crops under natural conditions and not associated with urban or rural development. These sites often contain tree species that are not currently utilized for industrial wood production or trees of poor form, small size, or inferior quality that are unfit for industrial products. Unproductivity may be the result of adverse site conditions such as sterile soil, dry climate, poor drainage, high elevation, and rockiness. This land is not withdrawn from timber utilization.

Other removals.-Growing-stock trees removed but not utilized for products, or trees left standing but "removed" from the timberland classification by land use change. Examples are removals from cultural operations such as timber stand improvement work, land clearing, and changes in land use.

Ownership size class.-The amount of timberland owned by one owner, regardless of the number of parcels.

Pasture.-Land presently used for grazing or under cultivation to develop grazing.

Poletimber stand.-(See Stand-size class.)

Poletimber tree.-A tree of commercial species at least 5.0 inches d.b.h. but smaller than sawtimber size.

Potential productivity class.-A classification of forest lands in terms of inherent capacity to grow crops of industrial wood. The class identifies the potential growth in merchantable cubic feet/acre/year at culmination of mean annual increment of fully stocked natural stands.

Reserved forest land.-Forest land withdrawn from timber utilization through statute, administrative regulation, designation, or exclusive use for Christmas tree production, as indicated by annual shearing.

Rotten tree.-A tree that does not meet regional merchantability standards because of excessive unsound cull. May include noncommercial tree species.

Rough tree.-A tree that does not meet regional merchantability standards because of excessive sound cull. May include noncommercial tree species.

Roundwood products.-Logs, bolts, or other round sections (including chips from roundwood ) cut from trees for industrial or consumer uses. (Note: Includes saw logs, veneer logs and bolts; cooperage logs and bolts; pulpwood; fuelwood; pilings; poles; posts; hewn ties; mine timbers; and various other round, split, or hewn products.)

Salvable dead tree.-A standing or down dead tree considered merchantable by regional standards.

Sapling.-A live tree 1.0 to 5.0 inches d.b.h.

Sapling-seedling stand.-(See Stand-size class.)

Saw log.-A log meeting minimum standards of diameter, length, and defect. A saw log must be at least 8 feet long, sound, straight, have a minimum diameter outside bark (d.o.b.) of 7.0 inches for softwoods and 9.0 inches for hardwoods, or have other combinations of size and defect specified by regional standards.

Saw-log portion.-That part of the bole of sawtimber trees between the stump and the saw-log top.

Saw-log top.-The point on the bole of sawtimber trees above which a saw log cannot be produced. The minimum saw-log top is 7.0 inches d.o.b. for softwoods and 9.0 inches d.o.b. for hardwoods. 
Sawtimber stand.-(See Stand-size class.)

Sawtimber tree.-A tree of commercial species containing at least a 12 -foot saw log or two noncontiguous saw logs 8 feet or longer, and meeting regional specifications for freedom from defect. Softwoods must be at least 9.0 inches d.b.h. Hardwoods must be at least 11.0 inches d.b.h.

Sawtimber volume.-Net volume of the sawlog portion of live sawtimber in board feet, International $1 / 4$-inch rule (unless specified otherwise), from the stump to a minimum 7 inches top d.o.b. for softwoods and a minimum 9 inches top d.o.b. for hardwoods.

Seedling.-A live tree less than 1.0 inch d.b.h. that is expected to survive. Only softwood seedlings more than 6 inches tall and hardwood seedlings more than 1 foot tall are counted.

Short-log (rough tree).-Sawtimber-size trees of commercial species that contain at least one merchantable 8 - to 11 -foot saw log, but not a 12 -foot saw log.

Site index.-An expression of forest site quality based on the height of a free-growing dominant, or codominant, tree of a representative species in the forest type at age 50.

Soft hardwoods. - Hardwood species with an average specific gravity less than 0.50 such as gum, yellow-poplar, cottonwood, red maple, basswood, and willow.

Softwoods.-Coniferous trees, usually evergreen, having needles or scale-like leaves.

Stand.-A group of trees on a minimum of 1 acre of forest land that is stocked by forest trees of any size.

Stand-age class.-Age of main stand. Main stand refers to trees of the dominant forest type and stand-size class.

Stand-size class.-A classification of stocked (see Stocking) forest land based on the size class of live trees on the area; that is, sawtimber, poletimber, or seedlings and saplings.

a. Sawtimber stands. - Stands with half or more of live stocking in sawtimber or poletimber trees, and with sawtimber stocking at least equal to poletimber stocking.

b. Poletimber stands.-Stands with half or more live stocking in poletimber and/or sawtimber trees, and with poletimber stocking exceeding that of sawtimber.

c. Sapling-seedling stands.-Stands with more than half of the live stocking in saplings and/or seedlings.

State land.-Land owned by States, or leased to them for 50 years or more.

Stocking.-The degree of occupancy of land by live trees, measured by basal area; and/or the number of trees in a stand by size or age and spacing, compared to the basal area; and/or number of trees required to fully utilize the growth potential of the land; that is, the stocking standard.

A stocking percent of 100 indicates full utilization of the site and is equivalent to 80 square feet of basal area per acre in trees 5.0 inches d.b.h. and larger. In a stand of trees less than 5 inches d.b.h., a stocking percent of 100 would indicate that the present number of trees is sufficient to produce 80 square feet of basal area per acre when the trees reach 5 inches d.b.h.

Stands are grouped into the following stocking classes:

Overstocked stands.-Stands in which stocking of live trees is 133 percent or more.

Fully stocked stands.-Stands in which stocking of live trees is from 100.0 to 132.9 percent.

Medium stocked stands.-Stands in which stocking of live trees is from 60.0 to 99.9 percent.

Poorly stocked stands.-Stands in which stocking of live trees is from 16.7 to 59.9 percent.

Nonstocked areas. - Timberland on which stocking of live trees is less than 16.7 percent.

Timberland.-Forest land that is producing, or capable of producing, in excess of 20 cubic feet per acre per year of industrial wood crops under natural conditions. In addition, the forest land must not be withdrawn from timber utilization, and not be associated with urban or rural development. Currently inaccessible and inoperable areas are included. 
Tree.-A woody plant usually having one or more perennial stems, a more or less definitely formed crown of foliage, and a height of at least 12 feet at maturity.

Tree grade.- A tree classification based on external characteristics as indicators of quality or value, used for hardwood species. (See Appendix for specific grading factors used.)

Tree size class.-A classification of trees based on diameter at breast height, including sawtimber trees, poletimber trees, saplings, and seedlings.

\section{Unproductive forest land.-Forest land} incapable of producing 20 cubic feet per acre per year of industrial wood under natural conditions because of adverse site conditions. (Note: Adverse conditions include sterile soils, dry climate, poor drainage, high elevation, steepness, and rockiness).

Upper stem portion.-That part of the bole of sawtimber trees above the saw-log top to a minimum top diameter of 4.0 inches outside bark, or to the point where the central stem breaks into limbs.

Water.-(a) Bureau of the Census.-Permanent inland water surfaces, such as lakes, reservoirs, and ponds at least 40 acres in area; and streams, sloughs, estuaries, and canals at least one-eighth of a statute mile wide.

(b) Noncensus.-Permanent inland water surfaces, such as lakes, reservoirs, and ponds from 1 to 39.9 acres in area; and streams, sloughs, estuaries, and canals from 120 feet to one-eighth of a statute mile wide.

Wooded pasture.-lmproved pasture with more than 16.7 percent stocking in live trees, but with less than 25 percent stocking in growing-stock trees. Area is currently improved for grazing or there is evidence of grazing.

\section{LITERATURE CITED}

Belcher, D.W.; Holdaway, M.R.; Brand, G.J. 1982. A description of STEMS the stand and tree evaluation and modeling system. Gen. Tech. Rep. NC-79. St. Paul, MN: U.S. Department of Agriculture, Forest Service, North Central Forest Experiment Station. 18 p.
Campbell, Robert A. 1964. Forest Service log grades for southern pine. Res. Pap. SE-11. Asheville, NC: U.S. Department of Agriculture, Forest Service, Southeastern Forest Experiment Station. 17 p.

Hackett, Ronald L.; Pilon, John. 1993. Michigan's timber industry-an assessment of timber product output and use, 1990. Resour. Bull. NC-144. St. Paul, MN: U.S. Department of Agriculture, Forest Service, North Central Forest Experiment Station. 56 p.

Hahn, Jerold T. 1984. Tree volume and biomass equations for the Lake States. Res. Pap. NC-250. St. Paul, MN: U. S. Department of Agriculture, Forest Service, North Central Forest Experiment Station. $10 \mathrm{p}$.

Hanks, Leland F. 1976. Hardwood tree grades for factory lumber. Res. Pap. NE-333. Broomall, PA: U.S. Department of Agriculture, Forest Service, Northeastern Forest Experiment Station. 81 p.

Hansen, Mark H. 1990. A comprehensive sampling system for forest inventory based on an individual tree growth model. St. Paul, MN: University of Minnesota, College of Natural Resources. 256 p. Ph.D. dissertation.

Little, Elbert L. 1981. Checklist of native and naturalized trees of the United States. Agric. Handb. 541. Washington, DC: U.S. Department of Agriculture, Forest Service. $385 \mathrm{p}$.

Loetsch, F.; Haller, K.E. 1964. Forest inventory, volume 1, statistics of forest inventory and information from aerial photographs. Vienna: BLV Verlagsgesellschaft Munch Basle. 436 p.

Peterson, Ted. 1965. Log grades. Spec. Circ. 60. Madison, WI: University of Wisconsin Extension Service, College of Agriculture. 4 p.

Rast, Everette D.; Sonderman, David L.; Gammon, Glenn L. 1973. A guide to hardwood log grading. Gen. Tech. Rep. NE-1. Upper Darby, PA: U.S. Department of Agriculture, Forest Service, Northeastern Forest Experiment Station. 31 p. 
Smith, W. Brad. 1983. Adjusting the STEMS regional growth models to improve local predictions. Res. Note NC-297. St. Paul, MN: U.S. Department of Agriculture, Forest Service, North Central Forest Experiment Station. 5 p.

VanDeusen, P.C.; Dell, T.R.; Thomas, C.E. 1986. Volume growth estimation from permanent horizontal points. Forest Science. 32: 415-422.

Wiant, Harry V., Jr.; Castenaeda, Froylan. 1977. Mesavage and Girard's volume tables formulated. BLM4. Denver, CO: U.S. Department of the Interior, Bureau of Land Management, Denver Service Center: 1-4.

\section{TABLE TITLES}

\section{Area}

Table 1.-Area by county and major land-use class, Western Upper Peninsula, Michigan, 1993

Table 2.-Area of timberland by county and ownership class, Western Upper Peninsula, Michigan, 1993

Table 3.-Area of timberland by county and forest type, Western Upper Peninsula, Michigan, 1993

Table 4.-Area of timberland by county and stand-size class, Western Upper Peninsula, Michigan, 1993

Table 5.-Area of timberland by county and potential productivity class, Western Upper Peninsula, Michigan, 1993

Table 6.-Area of timberland by county and stocking class of growing-stock trees, Western Upper Peninsula, Michigan, 1993

Table 7.-Area of timberland by forest type and ownership class, Western Upper Peninsula, Michigan, 1993

Table 8.-Area of timberland by ownership class and stocking class of growingstock trees, Western Upper Peninsula, Michigan, 1993
Table 9.-Area of timberland by forest type and stand-size class, Western Upper Peninsula, Michigan, 1993

\section{Number of Trees}

Table 10.- Number of all live trees on timberland by species group and diameter class, Western Upper Peninsula, Michigan, 1993

Table 11.-Number of growing-stock trees on timberland by species group and diameter class, Western Upper Peninsula, Michigan, 1993

\section{Volume}

Table 12.-Net volume of growing stock on timberland by species group and diameter class, Western Upper Peninsula, Michigan, 1993

Table 13.-Net volume of growing stock in the saw-log portion of sawtimber trees on timberland by species group and diameter class, Western Upper Peninsula, Michigan, 1993

Table 14.-Net volume of sawtimber on timberland by species group and diameter class, Western Upper Peninsula, Michigan, 1993

Table 15.-Net volume of growing stock and sawtimber on timberland by county and major species group. Western Upper Peninsula, Michigan, 1993

Table 16. - Net volume of timber on timberland by class of timber and major species group, Western Upper Peninsula, Michigan, 1993

Table 17.-Net volume of live trees and growing stock on timberland by ownership class and major species group. Western Upper Peninsula, Michigan, 1993

\section{Growth, Removals and Mortality}

Table 18.-Average net annual growth of growing stock and sawtimber on timberland by county and major species group. Western Upper Peninsula, Michigan, 1980-1992 
Table 19.-Average annual removals of growing stock and sawtimber on timberland by county and major species group. Western Upper Peninsula, Michigan, 1980-1992

Table 20.-Average net annual growth, average annual mortality, and average annual removals of growing stock and sawtimber on timberland by species group. Western Upper Peninsula, Michigan, 1980-1992

Table 21.-Average annual net growth and average annual removals of growing stock on timberland by ownership class and major species group. Western Upper Peninsula, Michigan, 1980-1992

Table 22.-Average annual net growth and average annual removals of sawtimber on timberland by ownership class and major species group, Western Upper Peninsula, Michigan, 1980-1992
Table 23.-Current annual net growth and mortality, and 1990 removals of growing stock and sawtimber on timberland by species group, Western Upper Peninsula, Michigan, 1992

\section{Log grade}

Table 24.--Net volume of sawtimber trees on timberland by species group and butt log grade (softwoods) or tree grade (hardwoods), Western Upper Peninsula, Michigan, 1993

\section{Other}

Table 25.-Comparison of adjusted 1980 and 1993 area and growing-stock volume by forest type, Western Upper Peninsula, Michigan 
Table 1.--Area by county and major land-use class, Western Upper Peninsula, Michigan, 1993

(In thousand acres)

\begin{tabular}{|c|c|c|c|c|c|c|c|}
\hline \multirow[b]{2}{*}{ County } & \multirow[b]{2}{*}{$\begin{array}{l}\text { Total land } \\
\text { and water }\end{array}$} & \multicolumn{4}{|c|}{ Forest land } & \multirow[b]{2}{*}{$\begin{array}{c}\text { Nonforest } \\
\text { land }\end{array}$} & \multirow[b]{2}{*}{$\begin{array}{c}\text { Census } \\
\text { water }\end{array}$} \\
\hline & & $\begin{array}{l}\text { All } \\
\text { forest } \\
\text { land }\end{array}$ & $\begin{array}{c}\text { Timber- } \\
\text { land }\end{array}$ & $\begin{array}{l}\text { Other } \\
\text { forest } \\
\text { land }\end{array}$ & $\begin{array}{l}\text { Reserved } \\
\text { timber- } \\
\text { land }\end{array}$ & & \\
\hline Baraga & 684.2 & 508.3 & 486.7 & 2.3 & 19.3 & 70.3 & 105.6 \\
\hline Dickinson & 497.4 & 398.2 & 398.2 & -. & -. & 92.3 & 6.9 \\
\hline Gogebic & 945.0 & 635.3 & 608.4 & - - & 26.9 & 70.0 & 239.7 \\
\hline Houghton & 961.0 & 540.4 & 528.9 & 1.6 & 9.9 & 107.1 & 313.5 \\
\hline Iron & 775.1 & 662.3 & 658.0 & 4.3 & - - & 84.2 & 28.6 \\
\hline Keweenaw & $3,878.7$ & 312.1 & 198.5 & 1.3 & 112.3 & 34.3 & $3,532.3$ \\
\hline Marquette & $2,193.2$ & $1,027.4$ & $1,005.1$ & 8.0 & 14.3 & 138.2 & $1,027.6$ \\
\hline Ontonagon & $2,394.5$ & 752.5 & 705.6 & -. & 46.9 & 87.0 & $1,555.0$ \\
\hline All counties & $12,329.1$ & $4,836.5$ & $4,589.4$ & 17.5 & 229.6 & 683.4 & $6,809.2$ \\
\hline
\end{tabular}

Table 2.--Area of timberland by county and ownership class, Western Upper Peninsula, Michigan, 1993

(In thousand acres)

\begin{tabular}{|c|c|c|c|c|c|c|c|c|c|}
\hline \multirow[b]{2}{*}{ County } & \multicolumn{9}{|c|}{ Ownership class } \\
\hline & $\begin{array}{c}\text { All } \\
\text { owners }\end{array}$ & $\begin{array}{c}\text { National } \\
\text { forest }\end{array}$ & $\begin{array}{l}\text { Misc. } \\
\text { federal }\end{array}$ & State & $\begin{array}{c}\text { County } \\
\text { and } \\
\text { municipal }\end{array}$ & Indian & $\begin{array}{c}\text { Forest } \\
\text { industry }\end{array}$ & $\begin{array}{c}\text { Misc. } \\
\text { private- } \\
\text { corporation } \\
\end{array}$ & $\begin{array}{c}\text { Misc. private- } \\
\text { individual/ } \\
\text { farmer }\end{array}$ \\
\hline Baraga & 486.7 & 33.7 & 10.1 & 57.9 & 1.3 & 6.4 & 252.4 & 23.9 & 101.0 \\
\hline Dickinson & 398.2 & - - & 1.6 & 195.9 & 4.0 & - & 38.6 & 34.8 & 123.3 \\
\hline Gogebic & 608.4 & 267.1 & -- & 2.7 & 57.7 & - & 123.7 & 66.2 & 91.0 \\
\hline Houghton & 528.9 & 141.5 & $\cdots$ & 40.3 & 5.8 & $\cdots$ & 89.6 & 101.6 & 150.1 \\
\hline Iron & 658.0 & 169.0 & -- & 73.8 & 3.1 & $\cdots$ & 95.9 & 153.4 & 162.8 \\
\hline Keweenaw & 198.5 & - & 1.3 & 1.2 & - - & - & 160.3 & 16.0 & 19.7 \\
\hline Marquette & $1,005.1$ & 5.0 & 1.4 & 224.5 & 14.2 & $\cdots$ & 171.4 & 293.2 & 295.4 \\
\hline Ontonagon & 705.6 & 247.1 & 2.7 & 20.4 & 3.9 & - & 153.8 & 144.3 & 133.4 \\
\hline All counties & $4,589.4$ & 863.4 & 17.1 & 616.7 & 90.0 & 6.4 & $1,085.7$ & 833.4 & $1,076.7$ \\
\hline
\end{tabular}




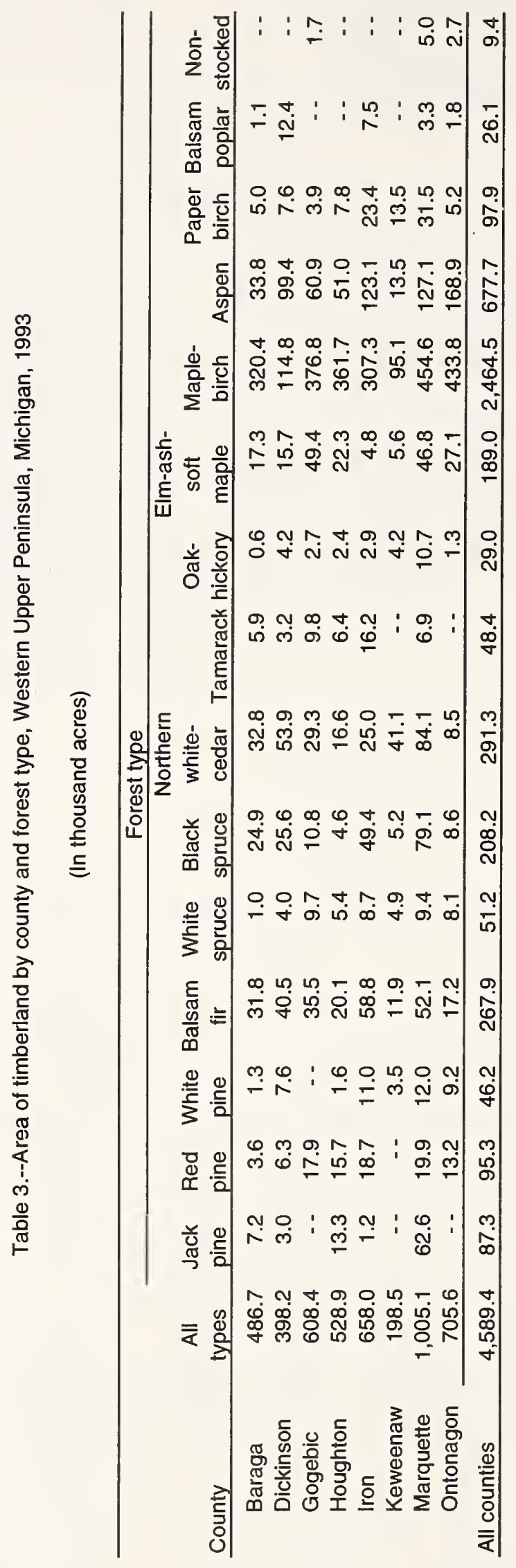


Table 4.--Area of timberland by county and stand-size class, Western Upper Peninsula, Michigan, 1993

(In thousand acres)

\begin{tabular}{|c|c|c|c|c|c|}
\hline \multirow[b]{2}{*}{ County } & \multirow[b]{2}{*}{ All stands } & \multicolumn{3}{|c|}{ Stand-size class } & \multirow{2}{*}{$\begin{array}{c}\text { Non- } \\
\text { stocked } \\
\end{array}$} \\
\hline & & Sawtimber & Poletimber & $\begin{array}{l}\text { Sapling and } \\
\text { Seedling }\end{array}$ & \\
\hline Baraga & 486.7 & 310.5 & 80.6 & 95.6 & - \\
\hline Dickinson & 398.2 & 151.2 & 155.4 & 91.6 & - \\
\hline Gogebic & 608.4 & 299.1 & 221.8 & 85.8 & 1.7 \\
\hline Houghton & 528.9 & 291.1 & 156.3 & 81.5 & - \\
\hline Iron & 658.0 & 289.6 & 182.2 & 186.2 & -- \\
\hline Keweenaw & 198.5 & 124.6 & 43.2 & 30.7 & $\cdots$ \\
\hline Marquette & $1,005.1$ & 458.6 & 264.6 & 276.9 & 5.0 \\
\hline Ontonagon & 705.6 & 345.5 & 191.0 & 166.4 & 2.7 \\
\hline All counties & $4,589.4$ & $2,270.2$ & $1,295.1$ & $1,014.7$ & 9.4 \\
\hline
\end{tabular}

Table 5.--Area of timberland by county and potential productivity class,

Western Upper Peninsula, Michigan, 1992

(In thousand acres)

\begin{tabular}{crrrrrrr}
\hline & & \multicolumn{5}{c}{$\begin{array}{c}\text { Potential productivity class } \\
\text { (cubic feet of }\end{array}$} \\
\cline { 3 - 8 } County & All classesth per acre per year) \\
\cline { 3 - 8 } & $225+$ & $165-224$ & $120-164$ & $85-119$ & $50-84$ & $20-49$ \\
\hline Baraga & 486.7 &.- & 1.2 & 8.8 & 65.9 & 215.6 & 195.2 \\
Dickinson & 398.2 &.- & 2.2 & 17.8 & 95.0 & 180.2 & 103.0 \\
Gogebic & 608.4 &.- & 1.2 & 43.8 & 103.6 & 262.4 & 197.4 \\
Houghton & 528.9 & 1.1 &.- & 22.2 & 103.9 & 295.3 & 106.4 \\
Iron & 658.0 & -- & 1.1 & 38.3 & 130.8 & 330.7 & 157.1 \\
Keweenaw & 198.5 & - & - & 1.2 & 12.9 & 53.4 & 131.0 \\
Marquette & $1,005.1$ & - & 1.3 & 29.9 & 122.7 & 397.9 & 453.3 \\
Ontonagon & 705.6 &.- & 1.8 & 23.7 & 159.1 & 367.9 & 153.1 \\
\cline { 2 - 8 } All counties & $4,589.4$ & 1.1 & 8.8 & 185.7 & 793.9 & $2,103.4$ & $1,496.5$ \\
\hline
\end{tabular}


Table 6.--Area of timberland by county and stocking class of growing-stock trees ${ }^{1}$, Western Upper Peninsula, Michigan, 1993

(In thousand acres)

\begin{tabular}{lrrrrrr}
\hline & \multicolumn{7}{c}{ Stocking class of growing-stock trees } \\
\cline { 2 - 7 } County & \multicolumn{7}{c}{$\begin{array}{c}\text { Non- } \\
\text { All classes }\end{array}$} & $\begin{array}{c}\text { Poorly } \\
\text { stocked }\end{array}$ & Moderately & Fully \\
stocked & stocked & Over- \\
stocked & stocked \\
\hline Baraga & 486.7 & -- & 41.2 & 178.0 & 141.8 & 125.7 \\
Dickinson & 398.2 & -- & 61.2 & 150.3 & 114.1 & 72.6 \\
Gogebic & 608.4 & 1.7 & 50.9 & 238.0 & 205.0 & 112.8 \\
Houghton & 528.9 & 12.1 & 53.3 & 194.3 & 182.6 & 86.6 \\
Iron & 658.0 & 1.8 & 72.1 & 191.8 & 226.2 & 166.1 \\
Keweenaw & 198.5 & -- & 13.7 & 81.0 & 63.1 & 40.7 \\
Marquette & $1,005.1$ & 6.4 & 92.6 & 337.1 & 260.3 & 308.7 \\
Ontonagon & 705.6 & 5.2 & 45.3 & 199.5 & 179.9 & 275.7 \\
All counties & $4,589.4$ & 27.2 & 430.3 & $1,570.0$ & $1,373.0$ & $1,188.9$ \\
\hline
\end{tabular}

1 This table is based on the stocking percent of growing-stock trees rather than that of all live trees. To use the definitions of stocking for this table, replace the term "all live" by "growing-stock."

2 Timberland insufficiently stocked with growing-stock trees. 


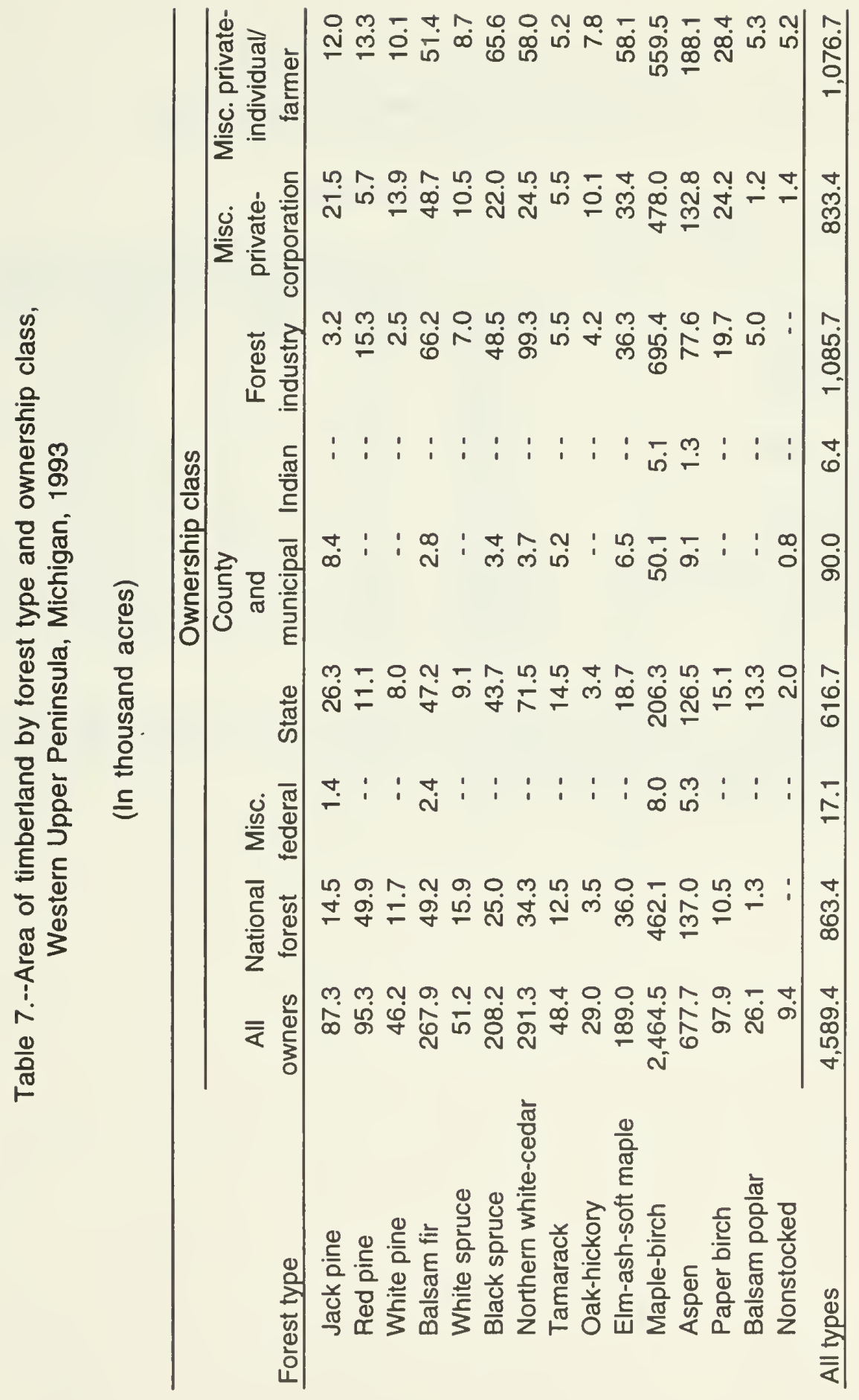


Table 8.--Area of timberland by ownership class and stocking class of growing-stock trees ${ }^{1}$, Western Upper Peninsula, Michigan, 1993

(In thousand acres)

\begin{tabular}{|c|c|c|c|c|c|c|}
\hline \multirow[b]{2}{*}{ Ownership class } & \multirow[b]{2}{*}{ All classes } & \multicolumn{5}{|c|}{ Stocking class of growing-stock trees } \\
\hline & & $\begin{array}{c}\text { Non- } \\
\text { stocked } 2\end{array}$ & $\begin{array}{l}\text { Poorly } \\
\text { stocked }\end{array}$ & $\begin{array}{l}\text { Moderately } \\
\text { stocked }\end{array}$ & $\begin{array}{c}\text { Fully } \\
\text { stocked }\end{array}$ & $\begin{array}{c}\text { Over- } \\
\text { stocked }\end{array}$ \\
\hline National forest & 863.4 & - & 21.9 & 138.0 & 298.8 & 404.7 \\
\hline Misc. federal & 17.1 & -- & 2.4 & 9.6 & 3.9 & 1.2 \\
\hline State & 616.7 & 2.0 & 81.9 & 202.6 & 157.2 & 173.0 \\
\hline County and municipal & 90.0 & 2.2 & 13.1 & 35.4 & 27.9 & 11.4 \\
\hline Indian & 6.4 & -- & - - & 2.6 & 1.3 & 2.5 \\
\hline Forest industry & $1,085.7$ & - & 82.7 & 455.2 & 322.0 & 225.8 \\
\hline Misc. private-corporation & 833.4 & 4.9 & 92.4 & 316.1 & 234.5 & 185.5 \\
\hline Misc. private-individual/farmer & $1,076.7$ & 18.1 & 135.9 & 410.5 & 327.4 & 184.8 \\
\hline All owners & $4,589.4$ & 27.2 & 430.3 & $1,570.0$ & $1,373.0$ & $1,188.9$ \\
\hline
\end{tabular}

1 This table is based on the stocking percent of growing-stock trees rather than that of all live trees. To use the definitions of stocking for this table, replace the term "all live" by "growing-stock."

2 Timberland insufficiently stocked with growing-stock trees. 
Table 9.--Area of timberland by forest type and stand-size class,

Western Upper Peninsula, Michigan, 1993

(In thousand acres)

\begin{tabular}{|c|c|c|c|c|c|}
\hline \multirow[b]{2}{*}{ Forest type } & \multirow[b]{2}{*}{ All stands } & \multicolumn{4}{|c|}{ Stand-size class } \\
\hline & & Sawtimber & Poletimber & $\begin{array}{l}\text { Sapling and } \\
\text { seedling }\end{array}$ & $\begin{array}{c}\text { Non- } \\
\text { stocked }\end{array}$ \\
\hline Jack pine & 87.3 & 44.0 & 13.2 & 30.1 & - \\
\hline Red pine & 95.3 & 48.4 & 24.6 & 22.3 & - - \\
\hline White pine & 46.2 & 38.2 & 2.6 & 5.4 & - \\
\hline Balsam fir & 267.9 & 110.5 & 72.6 & 84.8 & -- \\
\hline White spruce & 51.2 & 22.7 & 14.4 & 14.1 & - \\
\hline Black spruce & 208.2 & 23.1 & 71.6 & 113.5 & -- \\
\hline Northern white-cedar & 291.3 & 178.6 & 78.4 & 34.3 & -- \\
\hline Tamarack & 48.4 & 9.2 & 15.5 & 23.7 & -- \\
\hline Oak-hickory & 29.0 & 18.6 & 6.1 & 4.3 & - \\
\hline Elm-ash-soft maple & 189.0 & 77.4 & 62.5 & 49.1 & -- \\
\hline Maple-birch & $2,464.5$ & $1,442.7$ & 716.0 & 305.8 & - \\
\hline Aspen & 677.7 & 214.2 & 145.3 & 318.2 & - - \\
\hline Paper birch & 97.9 & 30.3 & 61.0 & 6.6 & - - \\
\hline Balsam poplar & 26.1 & 12.3 & 11.3 & 2.5 & - - \\
\hline Nonstocked & 9.4 & -. & -. & $\ldots$ & 9.4 \\
\hline All types & $4,589.4$ & $2,270.2$ & $1,295.1$ & $1,014.7$ & 9.4 \\
\hline
\end{tabular}




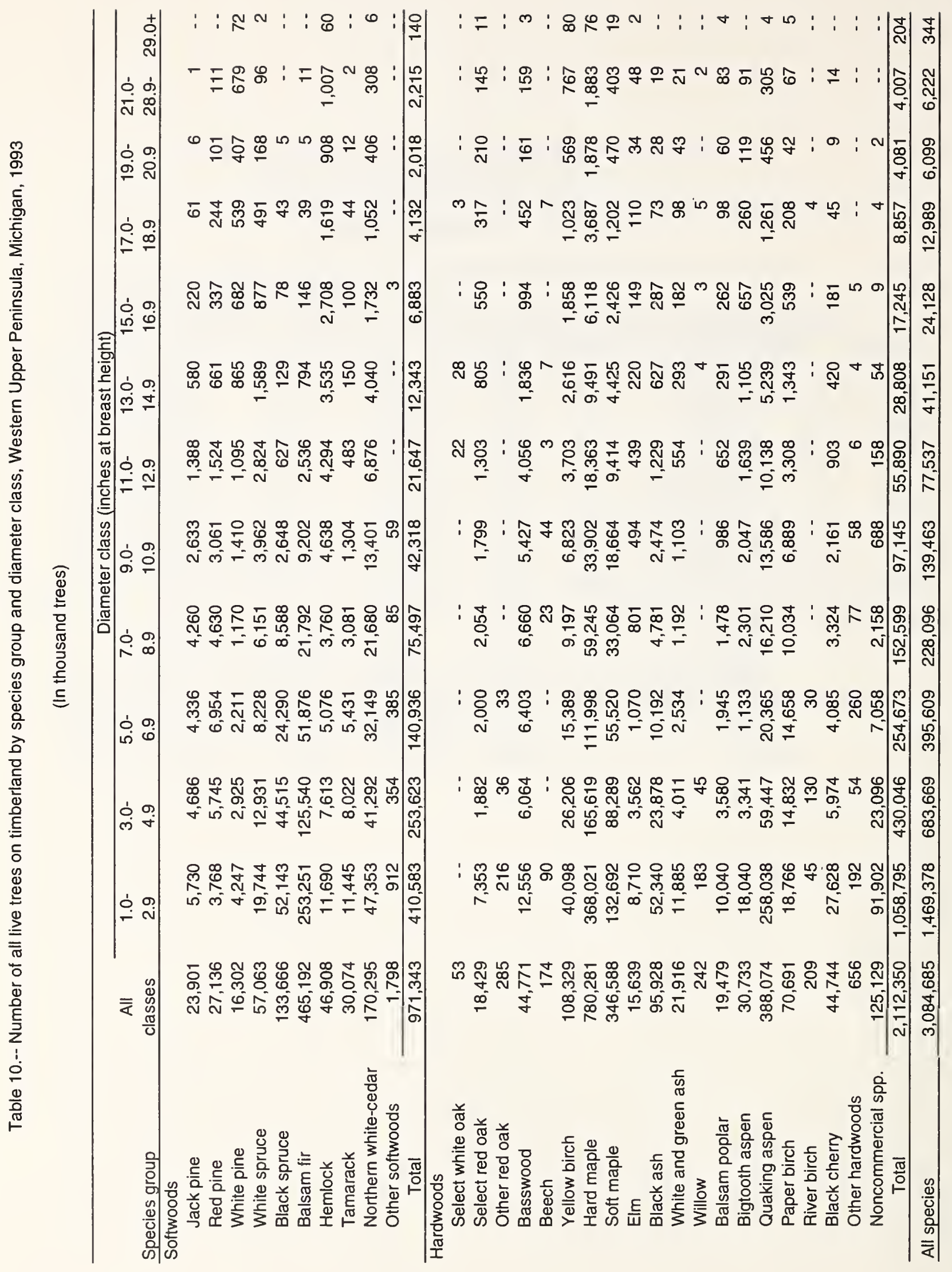




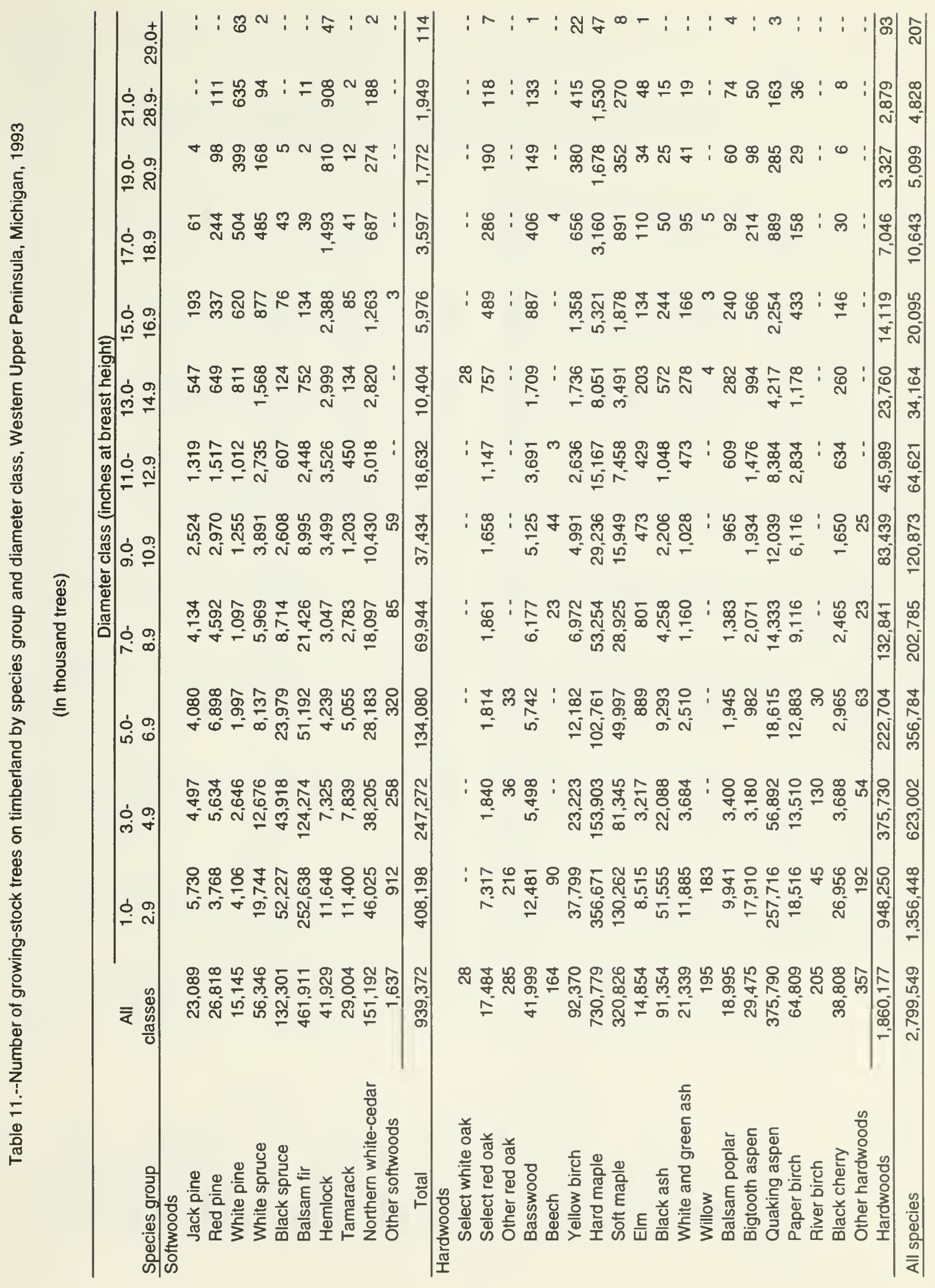




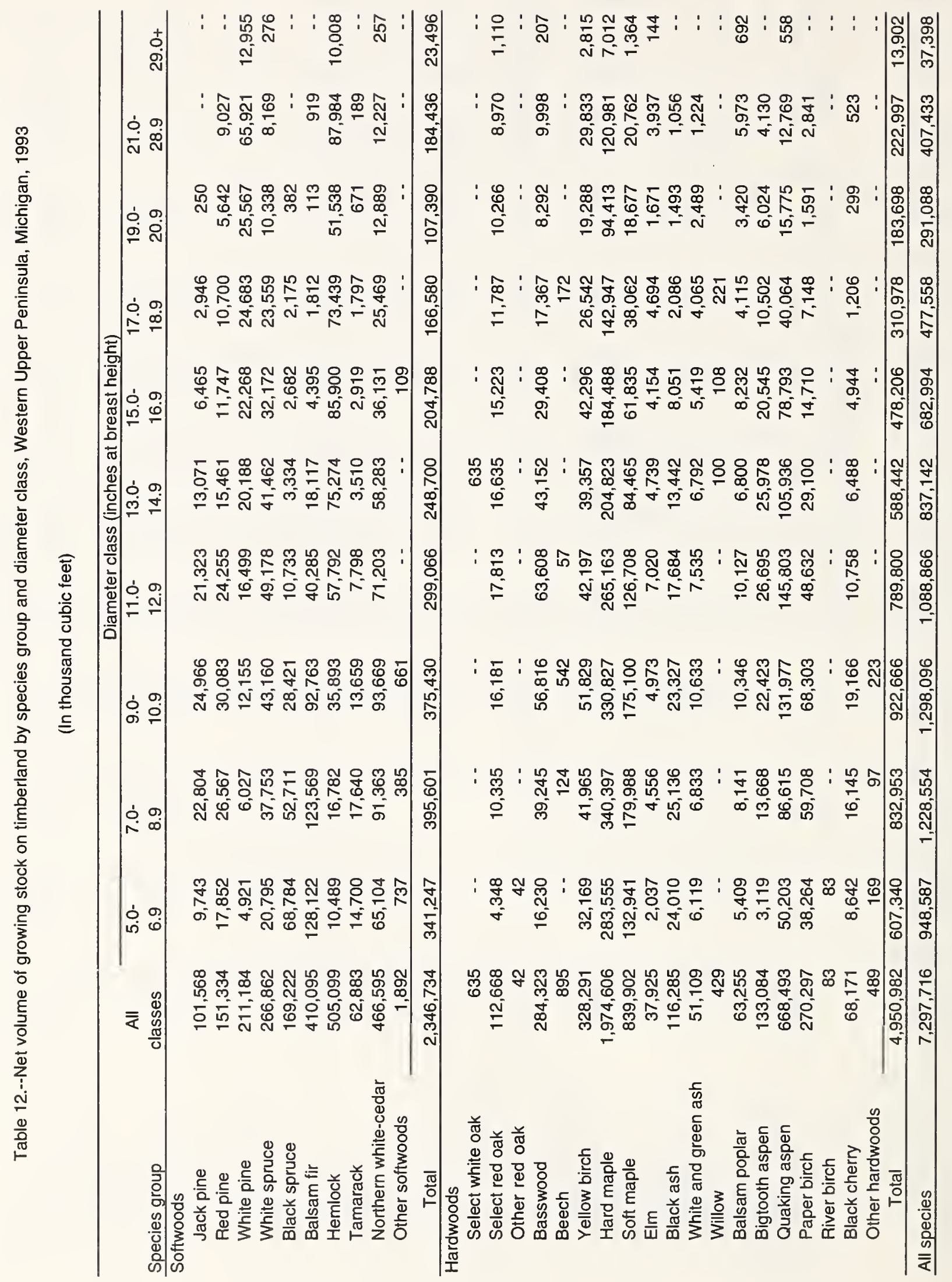


Table 13--Net volume of growing stock in the saw-log portion of sawtimber trees on timberland by species group and diameter class, Western Upper Peninsula, Michigan 1993

(In thousand cubic feet)

\begin{tabular}{|c|c|c|c|c|c|c|c|c|c|}
\hline \multirow[b]{2}{*}{ Species group } & \multirow[b]{2}{*}{$\begin{array}{c}\text { All } \\
\text { classes }\end{array}$} & \multicolumn{8}{|c|}{ Diameter class (inches at breast height) } \\
\hline & & $\begin{array}{l}9.0- \\
10.9 \\
\end{array}$ & $\begin{array}{c}11.0- \\
12.9 \\
\end{array}$ & $\begin{array}{c}13.0- \\
14.9 \\
\end{array}$ & $\begin{array}{l}15.0- \\
16.9 \\
\end{array}$ & $\begin{array}{c}17.0- \\
18.9 \\
\end{array}$ & $\begin{array}{l}19.0- \\
20.9 \\
\end{array}$ & $\begin{array}{l}21.0- \\
28.9 \\
\end{array}$ & $29.0+$ \\
\hline \multicolumn{10}{|l|}{ Softwoods } \\
\hline Red pine & 97,614 & 26,433 & 22,373 & 14,400 & 10,919 & 9,925 & 5,219 & 8,345 & - \\
\hline White pine & 172,793 & 9,388 & 13,874 & 17,355 & 19,297 & 21,464 & 22,282 & 57,696 & 11,437 \\
\hline Balsam fir & 132,403 & 74,967 & 34,927 & 16,039 & 3,920 & 1,621 & 102 & 827 & $\cdots$ \\
\hline Hemlock & 424,755 & 30,140 & 51,019 & 67,234 & 76,844 & 65,631 & 46,098 & 78,763 & 9,026 \\
\hline Tamarack & 26,998 & 11,642 & 7,020 & 3,212 & 2,681 & 1,653 & 616 & 174 & - - \\
\hline Northem white-cedar & 267,020 & 75,766 & 61,729 & 51,631 & 32,260 & 22,817 & 11,574 & 11,012 & 231 \\
\hline Other softwoods & 643 & 545 & $\ldots$ & $\ldots$ & 98 & - & - & -- & - \\
\hline Basswood & 124,816 & -- & 42,628 & 31,794 & 22,448 & 13,439 & 6,471 & 7,869 & 167 \\
\hline Beech & 176 & -- & 39 & - & - - & 137 & - & - & - - \\
\hline Yellow birch & 154,129 & $\cdots$ & 28,432 & 29,528 & 32,977 & 21,097 & 15,495 & 24,270 & 2,330 \\
\hline Hard maple & 739,011 & - & 170,718 & 147,447 & 138,330 & 109,326 & 72,991 & 94,611 & 5,588 \\
\hline Soft maple & 245,919 & -- & 80,049 & 59,801 & 45,771 & 28,830 & 14,291 & 16,098 & 1,079 \\
\hline Elm & 18,237 & $\cdots$ & 4,260 & 3,243 & 2,978 & 3,430 & 1,244 & 2,970 & 112 \\
\hline Black ash & 32,197 & $-\cdot$ & 12,190 & 10,087 & 6,247 & 1,641 & 1,187 & 845 & - - \\
\hline White and green ash & 20,080 & -- & 4,977 & 4,994 & 4,109 & 3,120 & 1,923 & 957 & -- \\
\hline Willow & 301 & -- & - - & 67 & 76 & 158 & - & - & - - \\
\hline Balsam poplar & 29,044 & -- & 6,830 & 4,993 & 6,252 & 3,154 & 2,643 & 4,630 & 542 \\
\hline Bigtooth aspen & 69,776 & $\cdots$ & 18,329 & 19,430 & 15,798 & 8,207 & 4,732 & 3,280 & - - \\
\hline
\end{tabular}




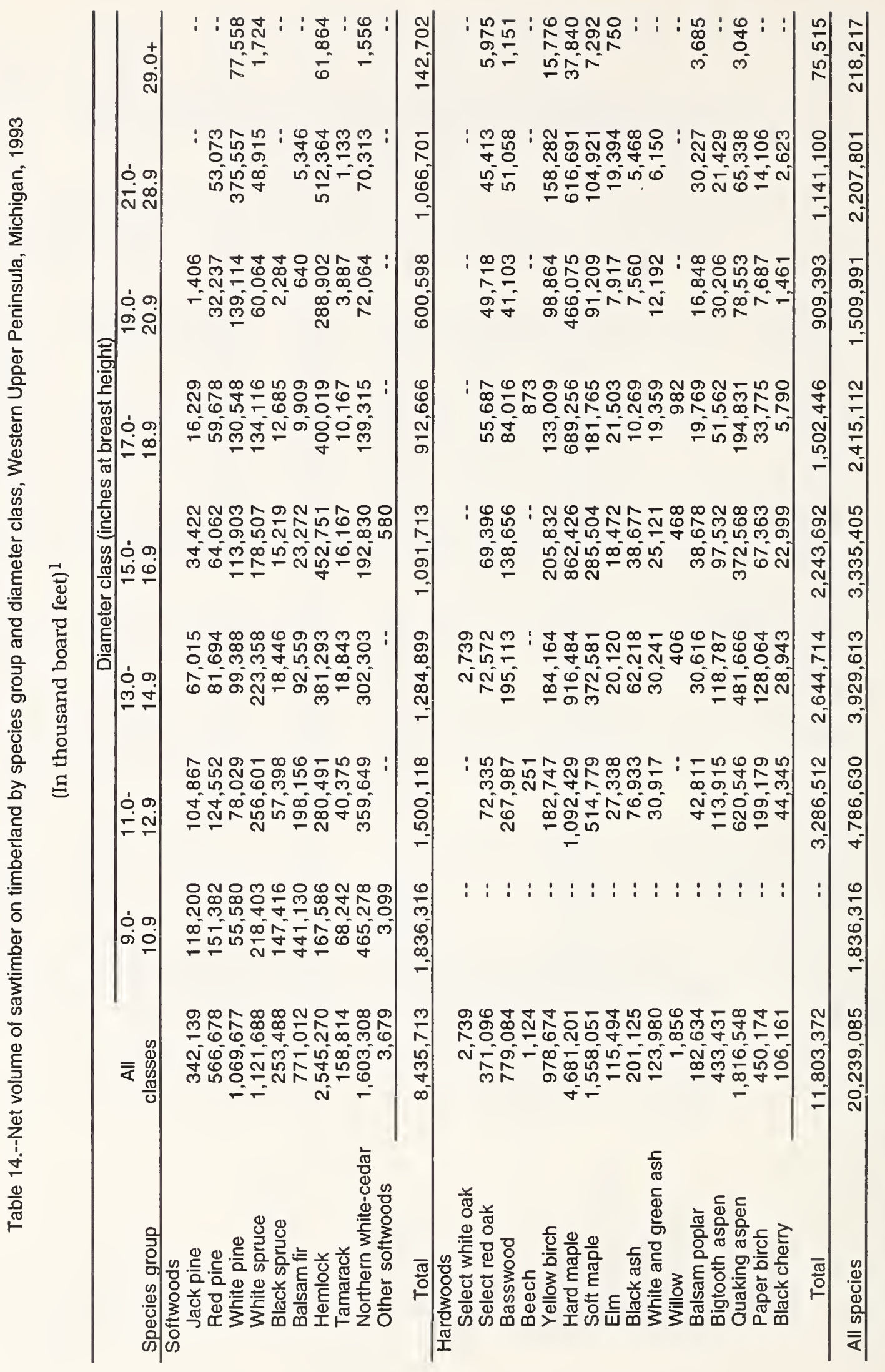

อี 


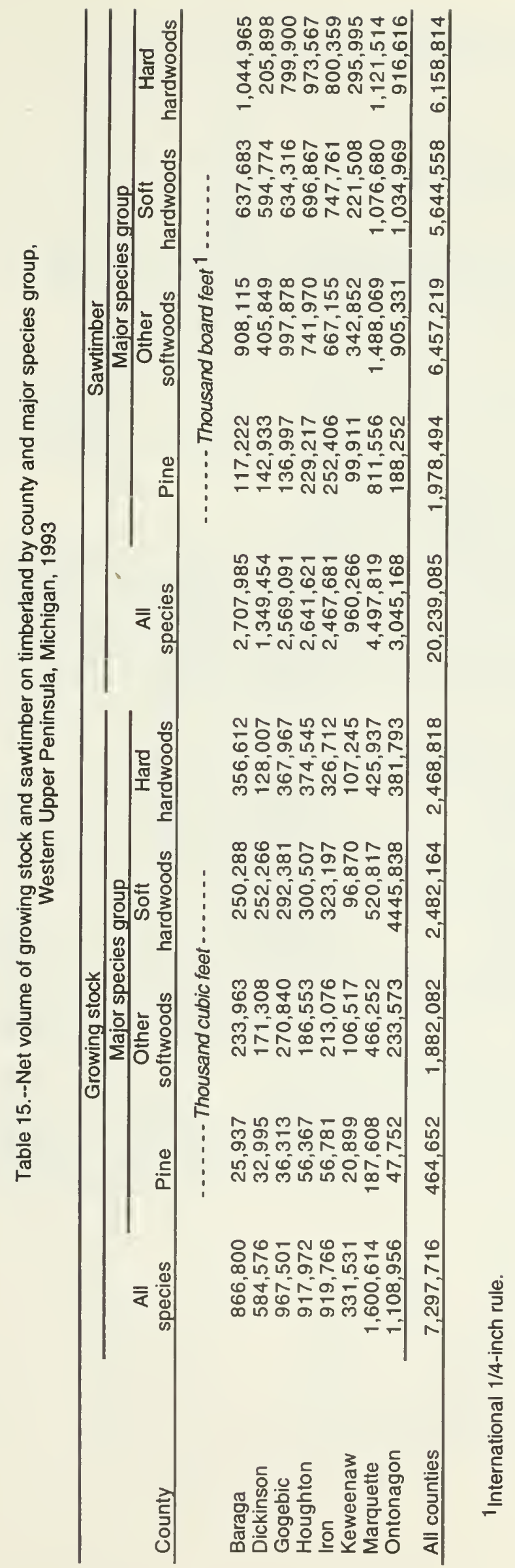


Table 16.--Net volume of timber on timberland by class of timber and major species group,

Western Upper Peninsula, Michigan, 1993

(In thousand cubic feet)

\begin{tabular}{|c|c|c|c|c|c|}
\hline \multirow[b]{2}{*}{ Class of timber } & \multirow[b]{2}{*}{$\begin{array}{c}\text { All } \\
\text { species }\end{array}$} & \multicolumn{4}{|c|}{ Species group } \\
\hline & & Pine & $\begin{array}{c}\text { Other } \\
\text { softwoods }\end{array}$ & $\begin{array}{c}\text { Soft } \\
\text { hardwoods }\end{array}$ & $\begin{array}{c}\text { Hard } \\
\text { hardwoods }\end{array}$ \\
\hline \multicolumn{6}{|l|}{$\begin{array}{l}\text { Live trees } \\
\text { Growing-stock trees } \\
\text { Sawtimber }\end{array}$} \\
\hline Saw-log portion & $3,287,933$ & 329,634 & $1,084,153$ & 868,718 & $1,005,428$ \\
\hline Upper stem portion & 909,874 & 46,538 & 149,459 & 343,146 & 370,731 \\
\hline Total & $4,197,807$ & 376,172 & $1,233,612$ & $1,211,864$ & $1,376,159$ \\
\hline Poletimber & $3,098,925$ & 88,480 & 647,568 & $1,153,933$ & $1,208,944$ \\
\hline All growing-stock trees & $7,296,732$ & 464,652 & $1,881,180$ & $2,365,797$ & $2,585,103$ \\
\hline Cull trees & & & & & \\
\hline $\begin{array}{l}\text { Short-log trees } \\
\text { Rough trees }\end{array}$ & 185,188 & 5,498 & 40,739 & 62,242 & 76,709 \\
\hline Sawtimber & 207,307 & 8,293 & 37,488 & 67,289 & 94,237 \\
\hline Poletimber & 263,632 & 2,271 & 25,989 & 88,324 & 147,048 \\
\hline Total & 470,939 & 10,564 & 63,477 & 155,613 & 241,285 \\
\hline Rotten trees & & & & & \\
\hline Sawtimber & 154,082 & 1,414 & 43,203 & 58,018 & 51,447 \\
\hline Poletimber & 39,386 & 17 & 5,656 & 19,074 & 14,639 \\
\hline Total & 193,468 & 1,431 & 48,859 & 77,092 & 66,086 \\
\hline All cull trees & 849,595 & 17,493 & 153,075 & 294,947 & 384,080 \\
\hline All live trees & $8,146,327$ & 482,145 & $2,034,255$ & $2,660,744$ & $2,969,183$ \\
\hline Salvable dead trees & & & & & \\
\hline Sawtimber & 51,638 & 2,553 & 20,285 & 23,774 & 5,026 \\
\hline Poletimber & 39,529 & 1,619 & 9,536 & 22,873 & 5,501 \\
\hline Total & 91,167 & 4,172 & 29,821 & 46,647 & 10,527 \\
\hline All classes & $8,237,494$ & 486,317 & $2,064,076$ & $2,707,391$ & $2,979,710$ \\
\hline
\end{tabular}




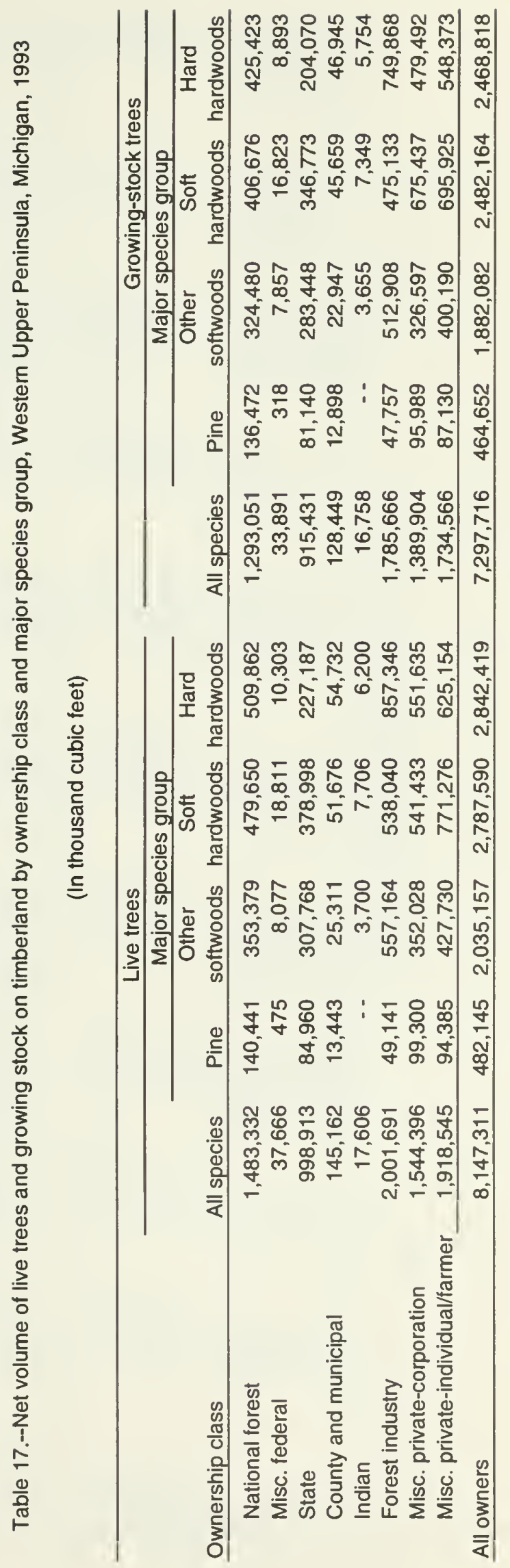




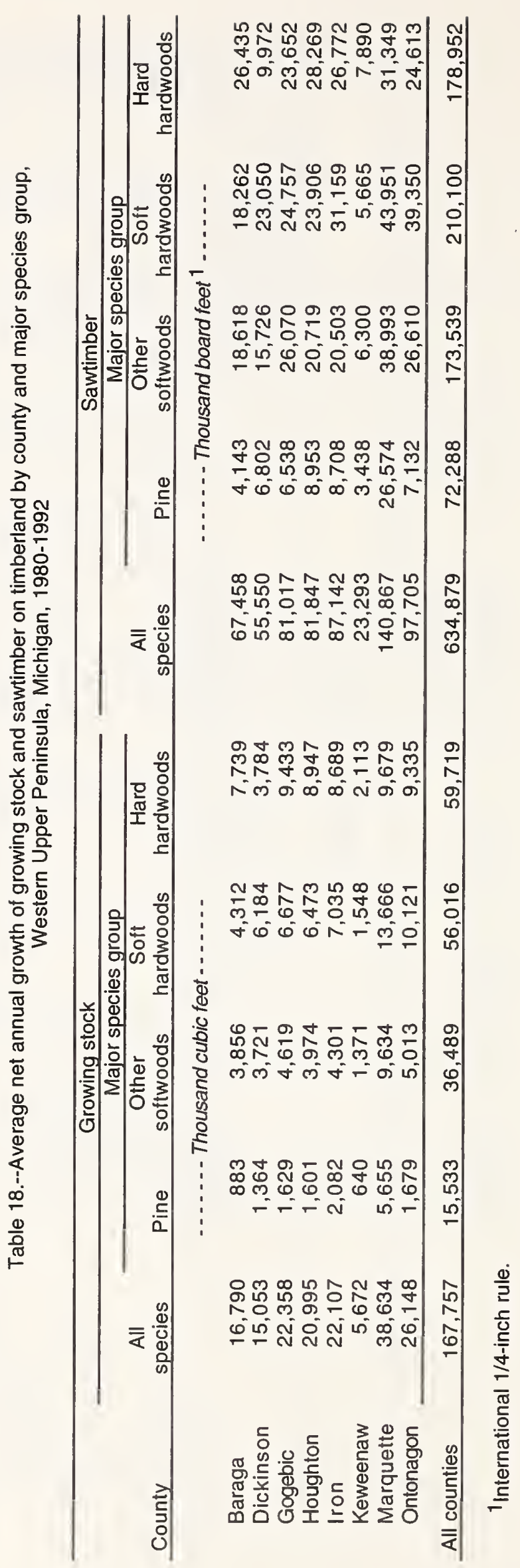




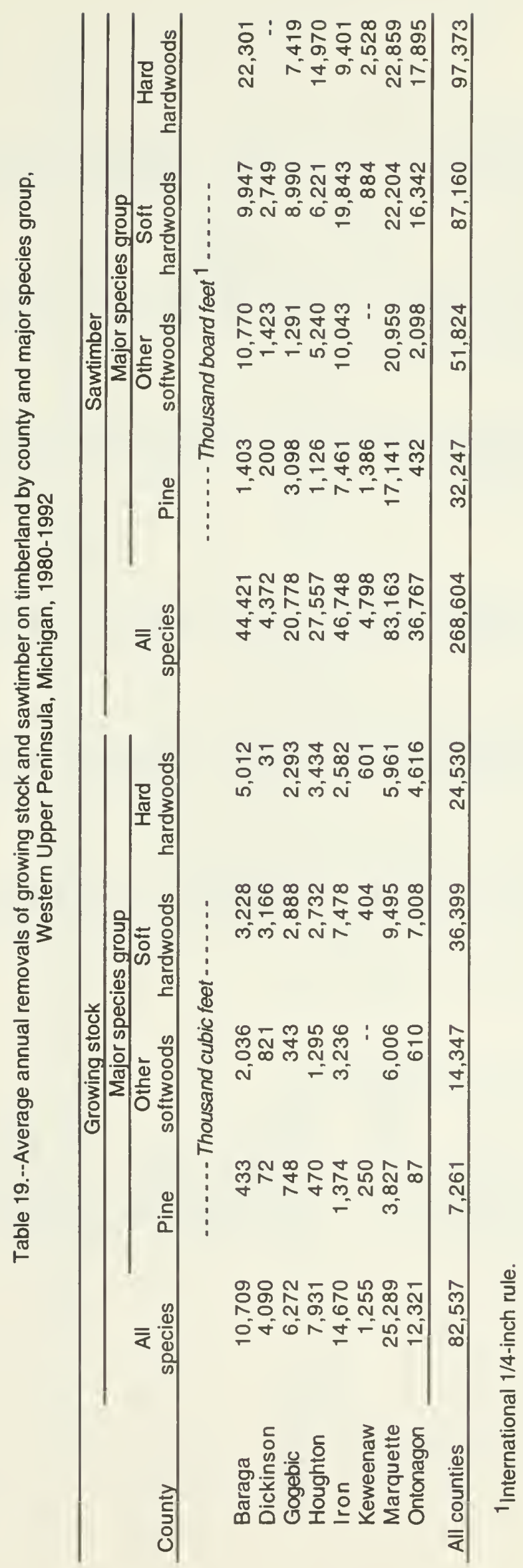




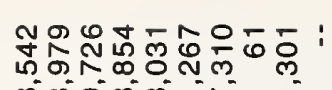

충 :下:

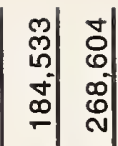

뚜요요

o

क⿺辶े

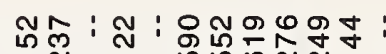

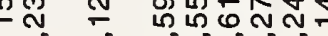

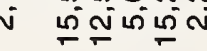

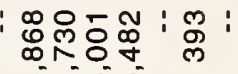

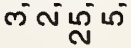

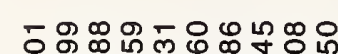

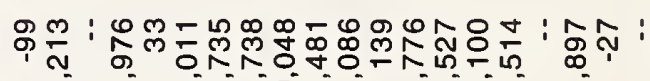

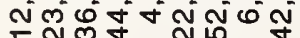

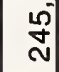

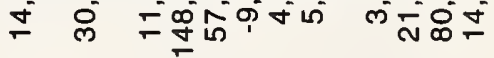

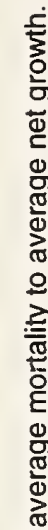

ชัด

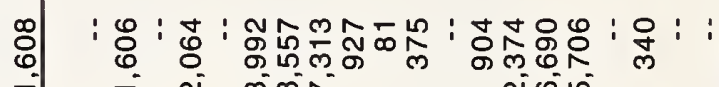

i

ลे

ஸ吊

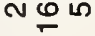

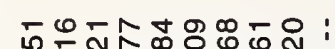

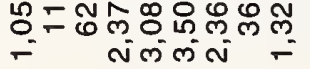

今a

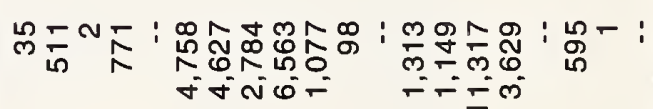

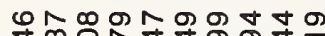

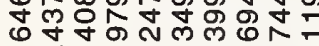
ก

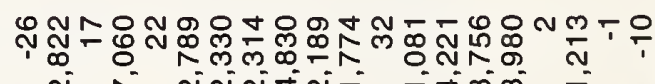
N

i⿱艹

过

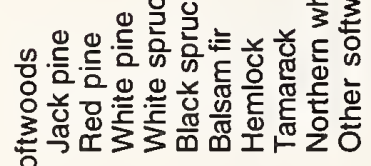

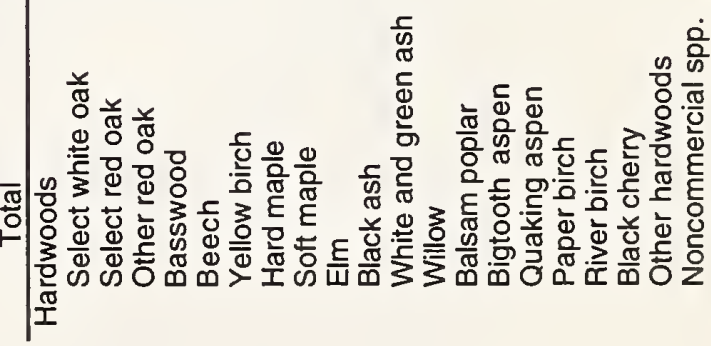




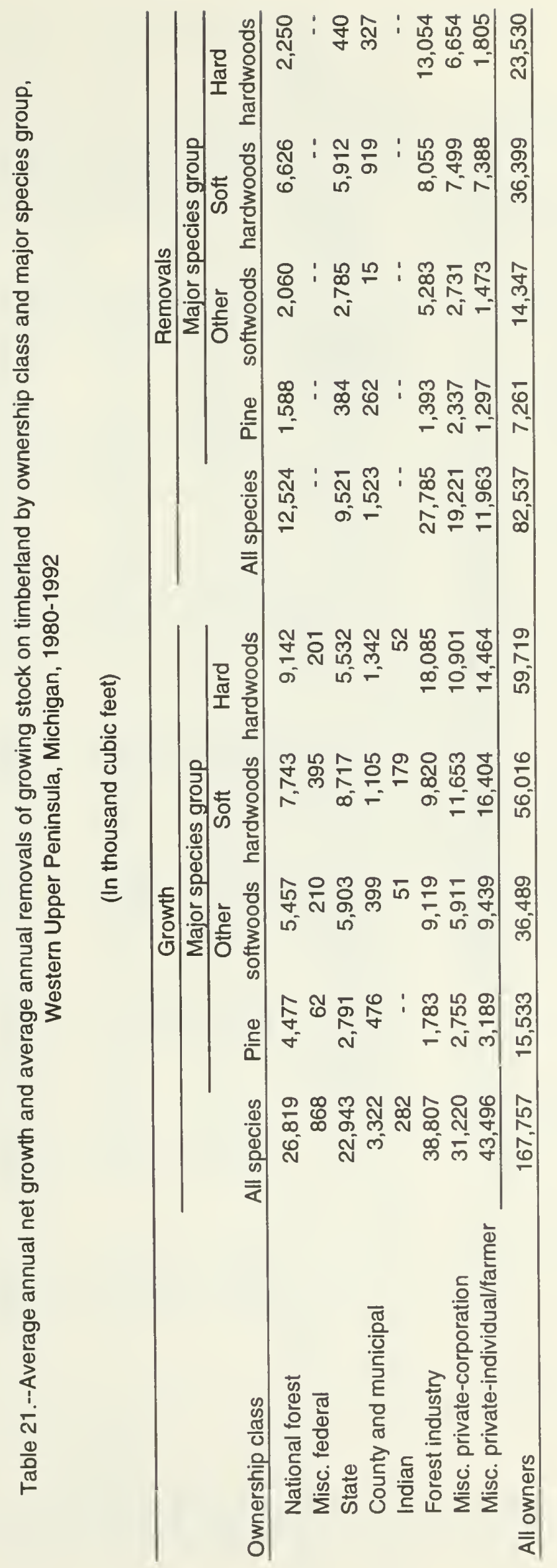




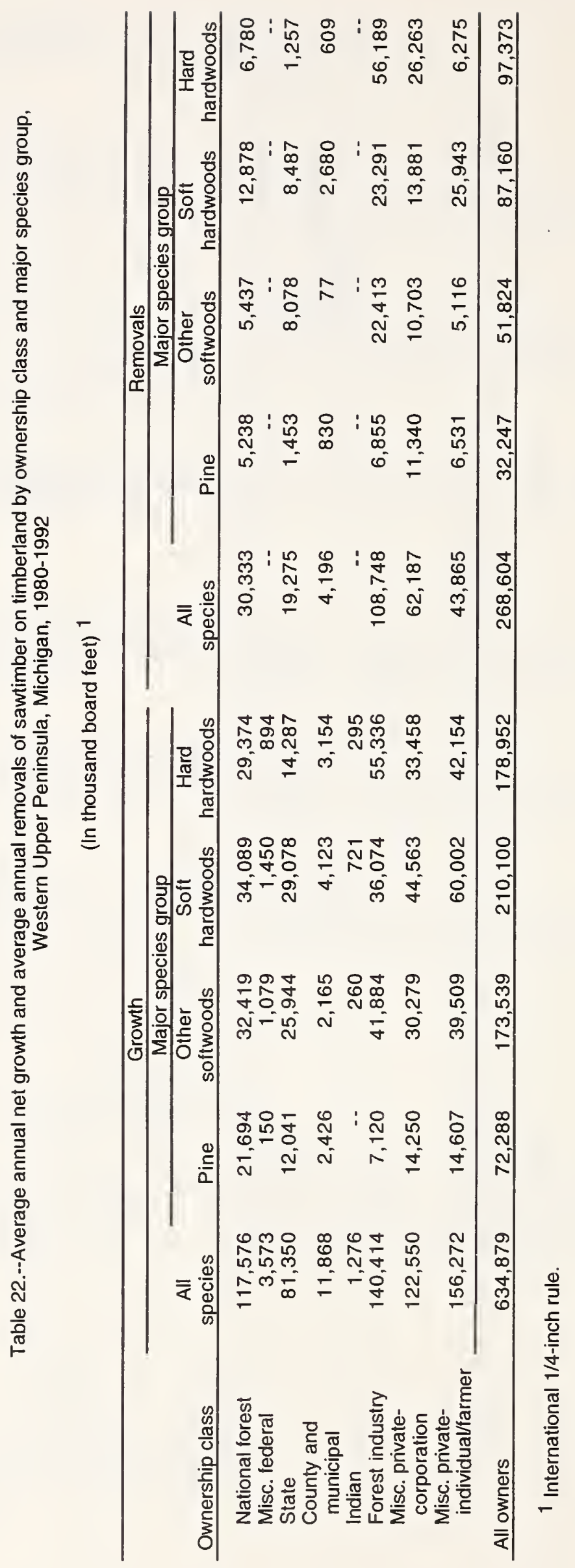


Table 23.--Current annual net growth and mortality, and 1990 removals of growing stock and sawtimber on timberland by species group, Western Upper Peninsula, Michigan, 1992.

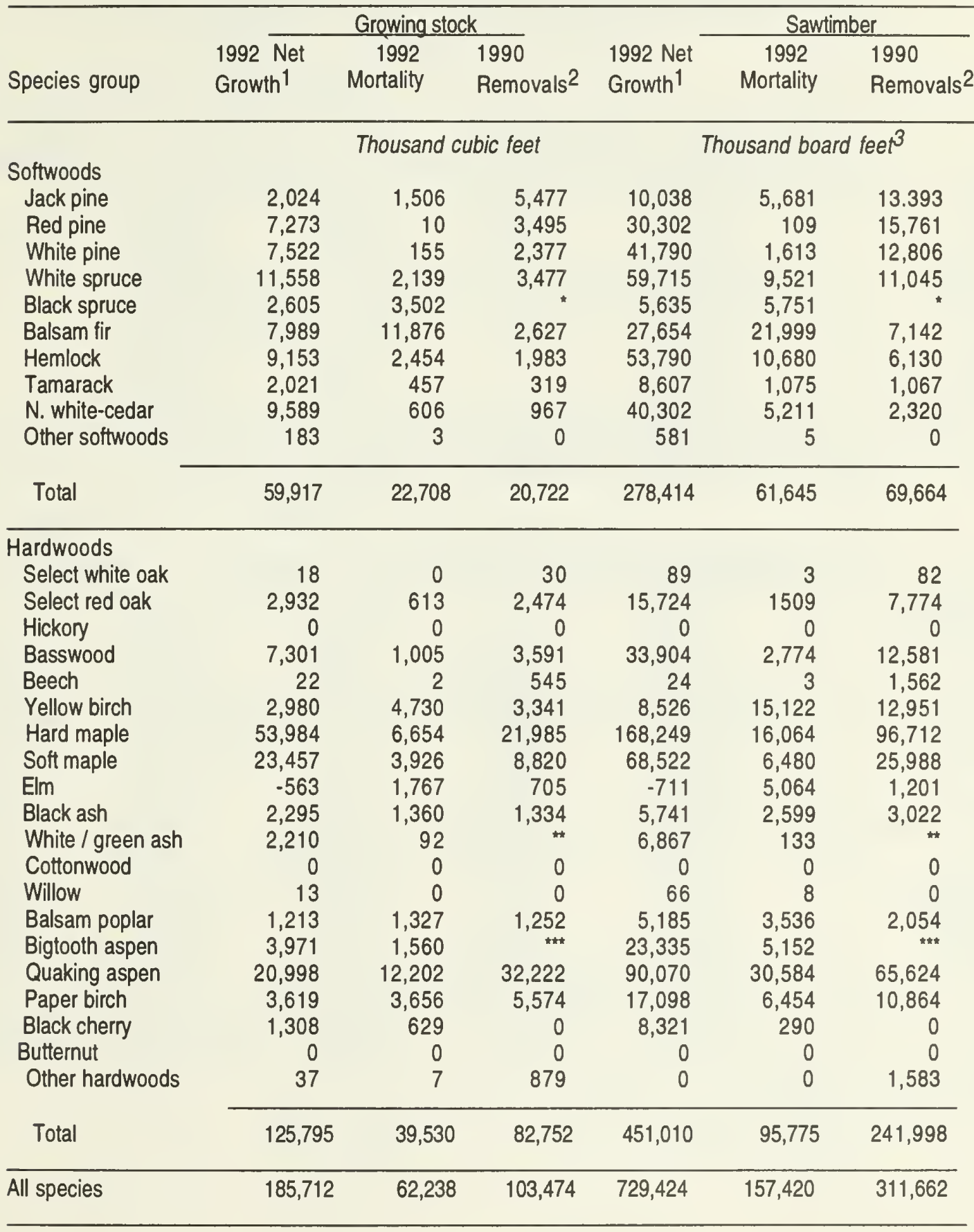

1 An estimate of current gross growth may be computed by adding current mortality to current net growth.

2 Based on mill survey data (Hackett and Pilon 1993). For the Western Upper Peninsula, 1990 is the most current mill survey.

3 International $1 / 4$-inch rule.

* Removals for the black spruce species group are included in the removals for white spruce.

* Removals for the white and green ash species group are included in the removals for black ash.

*** Removals for the bigtooth aspen species group are included in the removals for quaking aspen. 
Table 24.--Net volume of sawtimber trees on timberland by species group and butt log grade (softwoods) or tree grade (hardwoods), Western Upper Peninsula, Michigan, 1993

(In thousand board feet) ${ }^{1}$

\begin{tabular}{|c|c|c|c|c|c|}
\hline \multirow[b]{2}{*}{ Species } & \multirow[b]{2}{*}{$\begin{array}{c}\text { All } \\
\text { grades }\end{array}$} & \multicolumn{4}{|c|}{ Butt log grade } \\
\hline & & 1 & 2 & 3 & $\begin{array}{c}\text { Tie } \\
\text { and timber }\end{array}$ \\
\hline \multicolumn{6}{|l|}{ Softwoods } \\
\hline Jack pine & 342,139 & -- & 6,789 & 335,350 & -- \\
\hline Red pine & 566,678 & 122,278 & 32,942 & 411,458 & -. \\
\hline White pine & $1,069,677$ & 161,807 & 297,345 & 528,610 & 81,915 \\
\hline White spruce & $1,121,688$ & -- & 25,201 & $1,096,487$ & -. \\
\hline Black spruce & 253,448 & -. & -. & 253,448 & .- \\
\hline Balsam fir & 771,012 & -- & -. & 771,012 & -- \\
\hline Hemlock & $2,545,270$ & 38,487 & 231,338 & $2,275,445$ & -- \\
\hline Tamarack & 158,814 & -- & 12,712 & 146,102 & -. \\
\hline Northern white-cedar & $1,603,308$ & -. & 32,098 & $1,571,210$ & -- \\
\hline Other softwoods & 3,679 & -- & $\ldots$ & 3,679 & - \\
\hline Total & $8,435,713$ & 322,572 & 638,425 & $7,392,801$ & 81,915 \\
\hline & & \multicolumn{4}{|c|}{ Tree Grade } \\
\hline Species & $\begin{array}{c}\text { All } \\
\text { grades }\end{array}$ & 1 & 2 & 3 & $\begin{array}{c}\text { Tie } \\
\text { and timber }\end{array}$ \\
\hline \multicolumn{6}{|l|}{ Hardwoods } \\
\hline Select white oak & 2,739 & -- & -- & 2,739 & -- \\
\hline Select red oak & 371,096 & 78,666 & 113,355 & 150,213 & 28,862 \\
\hline Basswood & 779,084 & 141,130 & 223,036 & 393,336 & 21,582 \\
\hline Beech & 1,124 & 191 & 284 & 605 & 44 \\
\hline Yellow birch & 978,674 & 139,903 & 290,182 & 483,198 & 65,391 \\
\hline Hard maple & $4,681,201$ & 638,811 & $1,436,506$ & $2,262,453$ & 343,431 \\
\hline Soft maple & $1,558,051$ & 188,017 & 455,751 & 795,760 & 118,523 \\
\hline Elm & 115,494 & 115,494 & -. & & \\
\hline Black ash & 201,125 & 17,343 & 68,702 & 111,164 & 3,916 \\
\hline White and green ash & 123,980 & 15,984 & 44,854 & 61,318 & 1,824 \\
\hline Willow & 1,856 & 500 & 589 & 687 & 80 \\
\hline Balsam poplar & 182,634 & 49,185 & 57,945 & 67,606 & 7,898 \\
\hline Bigtooth aspen & 433,431 & 77,573 & 139,381 & 202,987 & 13,490 \\
\hline Quaking aspen & $1,816,548$ & 59,376 & 316,617 & $1,261,905$ & 178,650 \\
\hline Paper birch & 450,174 & 16,694 & 129,579 & 280,137 & 23,764 \\
\hline Black cherry & 106,161 & 3,242 & 42,169 & 51,793 & 8,957 \\
\hline Total & $11,803,372$ & $1,542,109$ & $3,318,950$ & $6,125,901$ & 816,412 \\
\hline All species & $20,239,085$ & $1,864,681$ & $3,957,377$ & $13,518,702$ & 898,325 \\
\hline
\end{tabular}

$1^{1}$ International 1/4-inch rule. 


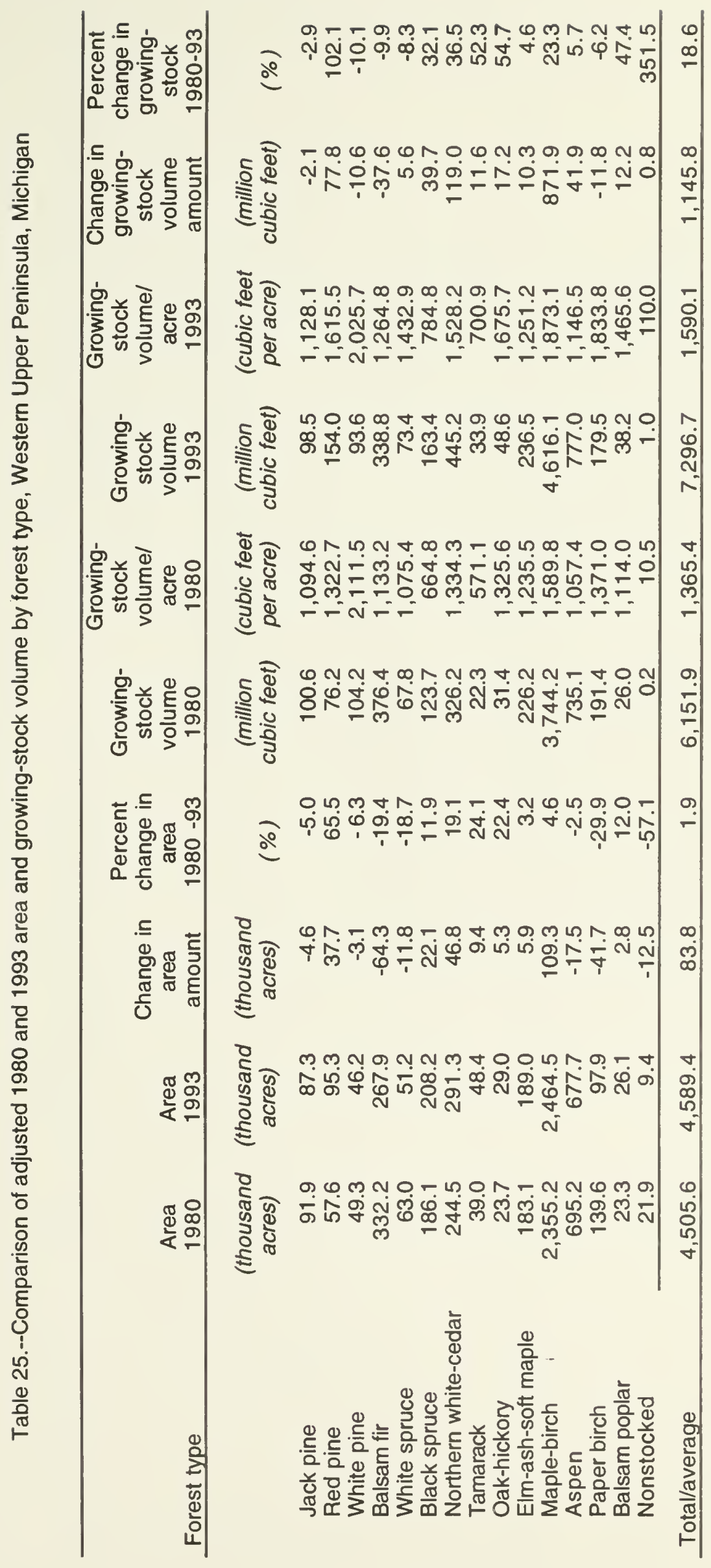





Leatherberry, Earl C.

1994. Forest statistics for Michigan's Western Upper Peninsula Unit, 1993. Resour. Bull. NC-153. St. Paul, MN: U.S. Department of Agriculture, Forest Service, North Central Forest Experiment Station. 45 p.

The fifth inventory of Michigan's Western Upper Peninsula Unit reports 12,329.1 million acres of land, of which 4,836.5 million acres are forested. This bulletin presents statistical highlights and contains detailed tables of forest area, as well as timber volume, growth, removals, mortality, and ownership.

KEY WORDS: Forest area, timber volume, growth, removals, mortality. 
Our job at the North Central Forest Experiment Station is discovering and creating new knowledge and technology in the field of natural resources and conveying this information to the people who can use it. As a new generation of forests emerges in our region, managers are confronted with two unique challenges: (1) Dealing with the great diversity in composition, quality, and ownership of the forests, and (2) Reconciling the conflicting demands of the people who use them. Helping the forest manager meet these challenges while protecting the environment is what research at North Central is all about. 